Amasya Ilahiyat Dergisi - Amasya Theology Journal

ISSN 2667-7326 | e-ISSN 2667-6710

Aralık / December 2020, 15: 239-273

\title{
Tekvîr Sûresi'ndeki “Hunnes”, “Cevâri” ve "Künnes” Kelimeleri Bağlamında Bir Bilimsel Tefsir Denemesi
}

\author{
Ahmet AKBAŞ \\ Dr. Öğr. Üyesi, Mardin Artuklu Üniversitesi, İslami İlimler Fakültesi, \\ Tefsir Anabilim Dalı \\ Assistant Professor, Mardin Artuklu University, Faculty of İslamic Sciences, \\ Department of Tafsîr \\ Mardin, Turkey \\ ahmetakbas101@hotmail.com \\ orcid.org/0000-0001-6939-5803
}

\section{Makale Bilgisi / Article Information}

Makale Türü / Article Types: Araştırma Makalesi / Research Article

Geliş Tarihi / Received: 29 Ağustos / August 2020

Kabul Tarihi / Accepted: 13 Ekim / October 2020

Yayın Tarihi / Published: 30 Aralık / December 2020

Yayın Sezonu / Pub. Date Season: Aralık / December

Sayı / Issue: 15 Sayfa / Pages: 239-273

Atıf / Cite as: Akbaş, Ahmet. "Tekvîr Sûresi'ndeki "Hunnes", "Cevâri" ve "Künnes" Kelimeleri Bağlamında Bir Bilimsel Tefsir Denemesi [An Essay on the Scientific Tafsir in the Context of the Words "Hunnes", "Cevâri" and "Kûnnes" from Surah at-Takwir]". Amasya İlahiyat Dergisi-Amasya Theology Journal 15 (December 2020): 239-273.

https://doi.org/10.18498/amailad.787642.

Intihal / Plagiarism: Bu makale, en az iki hakem tarafından incelendi ve intihal içermediği teyit edildi. / This article has been reviewed by at least two referees and scanned via a plagiarism software.

Copyright (c) Published by Amasya Üniversitesi, İlahiyat Fakültesi / Amasya University, Faculty of Theology, Amasya, 05100 Turkey. All rights reserved. https://dergipark.org.tr/amailad. 
240 I A. AKBAŞ / Tekvîr Sûresi'ndeki "Hunnes", "Cevâri” ve "Künnes" Kelimeleri Bağlamında Bir Bilimsel Tefsir Denemesi

\section{An Essay on the Scientific Tafsir in the Context of the Words "Hunnes", "Cevâri" and "Kûnnes" from Surah at-Takwir}

\section{Abstract}

In the Qur'an, although the literal meanings are known, there are some specific expressions concerning the scientific field based on experiment and observation in terms of their subjects, whose meanings have been discussed, that enter the research area of the scientific tafsîr method. Such statements can be better understood by the scientific findings obtained in the last century and more consistent explanations of what their purposes are. To conduct in-depth research on such expressions of the Qur'an is an effort to reveal its renewed direction in every century. Because the Qur'an has miraculous language and style characteristics that can also appeal to centuries ago. This shows that it is nor a human being, but the word of Allah, who knows everyting.

In this study, there are some expressions in the 15th and 16th verses of Takwir Surah that enter the research field of astronomy, which is one of the positive sciences. Many interpretations have been made in our interpretations of the words "hunnes", "cevârî" and "künnes" in the verses of past centuries and discussed at length what is pointed out by these words. The basis of the discussion is the question of whether these three words are sworn to deer, gazelles and antiloba or stars. Even if most commentators prefer the view that the stars are sworn in this verse, the issue of which stars are sworn and what qualities of these words emphasized that has been a separate topic of discussion. The relevant comments and discussions show that the statements in these verses are not fully understood, at least not a consensus. The fact that these explanations are not unconvincing in terms of containing irreconcilables make it necessary to reconsider these statements and to reinterpret them by taking advantage of the scientific accumulation of this century. Because these words are related to the space realm, which is one of the fields of scientific research. Today, it is obvious that the knowledge gained about the space realm and stars is too advanced to be even compared with the information at the time of the verses. When these expressions in the Takwir Surah are evaluated together with the available information about the space realm, it is concluded that a special type of star has been discovered here in recent years, and some scholars in the last century draw attention to this issue in the verses. Because in terms of its basic meanings, the word "hunnes" means privacy, invisibility and retreat and puckering, the word "cevârî" means fluency and mobility, and the word "kunnes" means sweeping and collecting. The verses begin with the oath 
"lâ uqsimu" that refers to strongly hard-indicating sworn to a physical phenomenon marked by the words "hunnes", "cevârî" and "kunnes". With the style of oath, which has a special place in the Qur'an, is drawn an attention to the fact that the oath is evidence of God's power and greatness. With the considering the usual view int he exegesis that these words in the verses mean stars, it is concluded that these verses point to the type of a star knwn as "black hole", whose invisibility and inward puckering, movement and fluency, as well as the ability of swallow objects around it, have been discovered in recent years. Because the black hole is also a type of star, their characteristics match the true meanings expressed by the words in the verses.

The fact that such a physical phenomenon has been pointed out in the Qur'an that reinforces the fact of the Allah Word, which is encompassed by its knowledge and power. The fact that such a physical phenomenon, which is discovered in the 20th century which the findings about it increased day by day was noted from centuries ago in the Quran which reconfirms the fact of Qur'an as Allah's word.

Keywords: Tafsir, Scientific Tafsir, Surah at-Takwir, Blackhole, Kûnnes.

\section{Tekvîr Sûresi'ndeki "Hunnes", "Cevâri" ve "Künnes" Kelimeleri Bağlamında Bir Bilimsel Tefsir Denemesi}

\section{Öz}

Kur'ân'da, lafzi anlamları bilinse de delaletleri tartışılmış olan, konuları itibariyle de deney ve gözleme dayalı bilimsel alanı ilgilendiren bazı özel ifadeler mevcut olup bunlar, bilimsel tefsir metodunun araştırma sahasına girmektedir. Bu tür ifadeler, son asırda elde edilen bilimsel bulgularla çok daha iyi anlaşılabilen ve delaletlerinin ne olduğu konusunda daha tutarlı açıklamalar yapilabilen ifadelerdir. Kur'ân' in bu tür ifadeleri üzerine derinlemesine araştırmalar yapmak, onun her asırda yenilenen i'câz yönünü açığa çıkarma gayretidir. Zira Kur'ân, asırlar öncesinden asırlar sonrasına da hitap edebilen mucizevi dil ve üslûp özelliklerine sahiptir. Bu da onun, bir beşerin değil, her şeye künhüyle vakıf olan Allah'ın kelâmı olduğunu göstermektedir.

Bu çalışmada ele alınan Tekvîr Sûresi 15-16. âyetlerde de pozitif bilimlerden biri olan astronominin araştırma sahasına giren bazı ifadeler mevcuttur. Âyetlerde geçen "hunnes", "cevârî" ve "künnes" kelimelerinin delaletleri hakkında geçmiş asırlardaki tefsirlerimizde birçok yorum yapılmış, bu kelimelerle neye işaret edildiği uzun uzadıya tartışılmıştır. Tartışmanın temelini ise bu üç kelime ile geyik, ceylan ve antiloba mı yoksa yıldızlara mı yemin edildiği meselesi oluşturmaktadır. Müfessirlerin ekseriyeti burada yıldızlara kasem edildiği 
242 I A. AKBAŞ / Tekvîr Sûresi'ndeki “Hunnes", "Cevâri" ve "Künnes" Kelimeleri Bağlamında Bir Bilimsel Tefsir Denemesi

görüşünü tercih etseler de hangi yıldızlara kasem edildiği ve bu kelimelerle onların hangi vasıflarının vurgulandığı hususu ayrı bir tartışma konusu olmuştur. İlgili yorumlar ve tartışmalar, bu âyetlerdeki ifadelerin tam olarak anlaşılamadığını, en azından bir görüş birliğinin bulunmadığını göstermektedir. Açıklamaların sadra şifa olmaması, birbirini nakzeden ve bazen de lafızlarla birebir uyuşmayan görüşler içermesi, bu ifadelerin yeniden ele alınmasını ve asrımızdaki bilimsel birikimden de istifade edilerek yeniden yorumlanmasını zaruri kılmaktadır. Zira bu kelimeler, bilimsel araştırma sahalarından olan uzay âlemiyle ilgilidir. Günümüzde uzay âlemi ve yıldızlar hakkında ulaşılmış olan bilgi birikiminin, âyetlerin indiği dönemdeki bilgilerle kıyas dâhi edilemeyecek kadar ileri seviyede olduğu aşikârdır. Tekvîr Sûresi'ndeki bu ifadeler, uzay âlemine dair mevcut bilgilerle birlikte değerlendirildiğinde, burada son yıllarda keşfedilmeye başlanan özel bir yıldız türüne işaret edildiği sonucuna varılmakta, son asırdaki bazı âlimler âyetlerin tefsirinde bu hususa dikkat çekmektedirler. Zira temel anlamları itibariyle "hunnes" kelimesi gizlilik, görünmezlik ve geri çekilip büzüşme, "cevârî" kelimesi akıcılık ve hareketlilik, "künnes" kelimesi ise süpürüp toplama gibi anlamları ifade etmektedir. Âyetlere "lâ uksimu" kasemiyle başlanarak, "hunnes", "cevârî" ve "künnes" kelimeleriyle işaret edilen fiziksel bir olguya güçlü ve vurgulu bir şekilde yemin edilmektedir. Kur'ân' da özel bir yeri olan bu güçlü yemin üslûbuyla, yemin edilen olgunun Allah'ın kudret ve azametine delil oluşuna dikkat çekilmektedir. Âyetlerdeki üç kelimenin temel anlamları ve kastedilenin yıldızlar olduğuna dair tefsirlerimizdeki baskın görüş dikkate alındığında, bu âyetlerde, görünmezlik ve içe doğru büzüşme, hareket ve akıcılık, bir de etrafındaki nesneleri silip süpürerek yutma özellikleri son yıllarda keşfedilmiş olan ve "karadelik" olarak bilinen yıldız türüne işaret edildiği sonucuna ulaşılmaktadır. Zira karadelikler de bir yıldız türü olup sahip oldukları özellikler, âyetlerdeki kelimelerin ifade ettiği hakiki anlamlarla birebir uyuşmaktadır.

Kur'ân' da böyle bir fiziksel olguya işaret edilmiş olması, onun, ilmi ve kudretiyle her şeyi kuşatmış olan Allah kelâmı olduğu hakikatini pekiştirmektedir. 20. asırda keşfedilmeye başlanan ve hakkındaki bulgular günbegün artan, bilim adamlarını hayretler içinde bırakan böyle bir fiziksel olguya Kur'ân'da asırlar öncesinden kasem edilerek dikkat çekilmiş olması, sûrenin devamında kasemin cevabı olarak vurgulanan, Kur'ân'ın Allah katından gelen bir kelâm oluşu gerçeğini pekiştirmektedir.

Anahtar Kelimeler: Tefsir, Bilimsel Tefsir, Tekvîr Sûresi, Karadelik, Künnes. 


\section{Giriş}

Kur'ân kendisini, "hidayet rehberi, nûr, hakikatin apaçık delili, hakkı batıldan ayıran ölçü, rahmet, şifa kaynağı"1 vb. ifadelerle tanitmakta, temel amacının tevhid merkezli bir hayat inşa etmek olduğuna işaret etmektedir. Dünya hayatında insana rehberlik etme iddiasını en güçlü şekilde dile getiren Kur'ân, bu iddiasını gerçekleştirmek üzere tek bir yol değil, çok çeşitli yol ve yöntemler kullanmaktadır. Zira o, insana rehberlik edebilmek için önce kendisine iman edilmesini sağlamak zorundadır. İnsanın, onun rehberliğine şeksiz şüphesiz teslim olması için her şeyden önce Allah tarafından gelen mesajlarla dolu olduğunu kalpten kabul etmesi gerekmektedir. Kur'ân'ın, ona muhatap olan ilk nesilde bu teslimiyeti temin eden en etkili özelliği, muhataplarının daha önce hiç şahit olmadıkları kadar güçlü ve etkili olan dili ve üslûbu, belagat ve fesahati olmuştur. $\mathrm{O}$, sözün kılıçtan daha keskin olduğu, şiirin ve söz sanatının adeta zirvelere ulaştığ1 bir topluma hitap etmiştir. Böyle bir dönemde nazil olmaya başlayan Kur'ân, sahip olduğu eşsiz üslûp ile tüm sözleri geride bırakmış, şiirin ustalarını dahi lal etmiş, kalpleri titreten etkisiyle nice gönlü kazanmış ve kazandığı bu gönüllerin onu rehber edinmelerini sağlamıştır. ${ }^{2}$

Ancak Kur'ân'ın insanı etkileme yönünü, sadece fesahat ve belagatinde görmek doğru mudur? $\mathrm{O}$, hala bu yönüyle mi mucizedir yoksa onun, insanların kendisine teslim olmasını temin edecek başka mucizevi yönleri de var mıdır? Tam da burada İsmail Cerrahoğlu'nun şu sözlerine bir kez daha kulak vermek yerinde olacaktır: "Kur'ân'ın i'cazı pek çok yönlerde tecelli eder. Onun i'cazını sadece dili, üslûbu ve fesahatinde aramak hatadır." 33 Bu hataya düşmemek için Kur'ân'ın i'cazını, sadece dil ve üslûbunda değil, verdiği gaybi haberlerde, hayata dair ilkelerinin insan fitratı ile birebir uyuşmasında, insana, topluma ve evrene dair ifadelerinde de aramak gerekmektedir. Zira o, asırlar

1 el-Bakara 2/185; el-Mâide 5/15-16; Yunus 10/57; el-İsra 17/9, 82; İbrahim 14/1; elHadid 57/9.

2 Muhammed Abdulazim ez-Zerkanî, Menâhilü'l-'irfân fì 'Ulûmi'l-Kur'ân (Beyrut: Dâru'l-Marife, 2005), 2/218.

3 İsmail Cerrahoğlu, Tefsir Usûlü (Ankara: Türkiye Diyanet Vakfı Yayınları, 2007), 163. 
244 | A. AKBAŞ / Tekvîr Sûresi'ndeki “Hunnes", "Cevâri” ve "Künnes” Kelimeleri Bağlamında Bir Bilimsel Tefsir Denemesi

geçtikçe daha iyi anlaşılan, dünya yaşlandıkça gençleşen ve sırları keşfedilen ilahi bir kelâmdır. ${ }^{4}$

Kur'ân'ın geçmiş asırlarda keşfedilmemiş olan yönlerini ortaya çıkarmak için kullanılan yöntemlerden biri de son asırda öne çıkan bilimsel tefsir metodudur. Geçmiş asırlarda ilk nüveleri mevcut olan, ${ }^{5}$ son yıllardaki çalışmalarla da günbegün gelişen bu metodun en temel amacı, Kur'ân'ın dili, üslûbu ve fesahatindeki mucizeleri dişında, bilim ve teknoloji çağının insanına hitap eden bir yönünün de olduğunu delilleriyle ispat etmektir. Zira son asırdaki bilimsel keşiflerle mutabık olduğu anlaşılan âyetler, onun yeni bir mucizevi yönünü daha ortaya çıkarmıştır. Kur'ân'daki bu tür ifadeler, elbette ki esas itibariyle bilimsel bilgi verme amacı taşımamaktadır. Onun bu türden âyetlerini, bilimi kutsal görmeye başlayan günümüz insanı için Kur'ân'ın Allah kelâmı olduğunu kabule götürecek muasır mucizeler olarak telakki etmek en doğru yaklaşımdır. ${ }^{6}$

Kur'ân'ın nihai amacının insanın hidayeti olması, evren hakkında bazı bilgiler vermesine engel değildir. Hatta Kur'ân'ın, ilk muhatapların sathi olarak anladıkları, sonraki çağlardaki insanların ise -elde ettikleri modern bilgi ve bulgularla- çok daha detaylı ve derinlemesine idrak ettikleri bazı ifadeler içermesi, onun hidayet amacına yardımcı olan gayet önemli bir unsurdur. ${ }^{7}$ Kur'ân'da, ancak bilimsel gelişmeler ve keşiflerle künhüne varılan bu tür âyetlerin varlığı, aklı kutsayan modern muhatapları şaşırtan ve Kur'an'ın beşer ötesi bir kaynaktan geldiğini kabullenmelerini temin eden bir etkiye sahiptir. Kur'ân'daki bazı âyetlerin bilimsel tefsir metodu ile yorumlanmaya çalışılması, bu yönüyle büyük önem arz etmektedir. Ancak bu alanda kötü örnekler ortaya koyanlar, ifrata kaçanlar, usûl ve kaideleri dikkate almadan keyfi

4 Said Nursi, Sözler (İstanbul: Sözler Yayınları, ts.), 378; Said Nursi, Mektûbât (İstanbul: Sözler Yayınları, ts.), 447.

5 Ebû Hâmid Muhammed el-Gazzâlî, İhyâu Ulumi'd-Din (Beyrut: Dâru İbn Hazm, 2005), 1/341-342; Cerrahoğlu, Tefsir Usûlü, 303-305; Veysel Güllüce, Bilimsel Tefsirde Usûl (Erzurum: Aktif Yayınevi, 2007), 11-20; Mehmet Bağ1ş, Beydâvî Tefsirinde Kur'ân İlimleri ve Tefsir Usûlü (Şırnak: Şırnak Üniversitesi Yayınları, 2018), 239-255.

6 Bahattin Dartma, “İlmî Bir Tefsir Denemesi: Kur'ân Bağlamında Dünya Dışındaki Gök Cisimlerinde Canlı Varlıkların Olabileceğine Dair", Dinbilimleri Akademik Araştırma Dergisi 4/4 (2004), 8-9.

7 Zerkanî, Menâhilü'l-'Irfân, 2/234; Ömer Çelik, Tefsir Usûlü ve Tarihi (İstanbul: Kampanya Kitapları, 2015), 111-112. 
yorum yapanlar olduğu gibi, art niyetlerle ve bu kıymetli yöntemi baltalamak kastıyla alanda boy gösterenler de yok değildir. Bu nedenlerle bilimsel tefsir metodunun çerçevesini çizmek ve ilkelerini belirlemek adına güzel çalışmalar yapılmıştır. "Su-i misal emsal olmaz" kaidesinden hareketle kötü örnekleri bir tarafa bırakarak ve işin ehlince ortaya konmuş olan prensiplere bağlı kalarak Kur'ân'ın bu tür ifadeleri üzerindeki örtüler kaldırılmalıdır.

Şu da unutulmamalıdır ki Kur'ân'ın çeşitli ifadelerini en sahih şekilde yorumlamak için başlangıçtan günümüze birçok farklı disiplinden istifade edilmiştir. Hz. Peygamber'den ve sahabeden gelen rivayetler, cahiliye şiiri, dil ve belagat kuralları, İsrâiliyat kaynaklı rivayetler, tecrübi bilgiler, tarihî ve arkeolojik veriler vs. bunlar arasında sayılabilir. Aynı şekilde Kur'ân'ın bazı ifadelerinin, modern çağın bilimsel keşif ve bulguları ışı̆̆ında anlaşılmaya çalışılması da gayet tabidir. Ancak bu iş, belli bazı kıstaslar çerçevesinde yapılmadıkça doğru sonuca ulaşmak mümkün değildir. $\mathrm{Bu}$ nedenledir $\mathrm{ki}$ işin öneminin farkında olanlarca bu alanda bir metodoloji belirleme gayreti gösterilmiştir. Biz de bu eserlerde ortaya konan metodolojiye riayet ederek Tekvîr Sûresi 15-16. âyetlerde geçen ifadeleri, bilimsel tefsir metoduna göre yorumlamaya çalışacağız.

\section{Tekvîr Sûresi'nin Genel Muhtevası}

Mushaf tertibi itibariyle 81. sûre olan Tekvîr Sûresi, Mekke döneminde nazil olmuştur ve 29 âyetten müteşekkildir. Nüzûl sırası itibariyle 7. sûre olduğu görüşü tercih edilmektedir. Sûre, ismini ilk âyetinde geçen ve " “خَّرَ" fiilinin meçhul (edilgen) formu olan " kelimesinden almıştır. Tekvîr, "dürdü, büzdü, sardı, doladı" anlamına gelen " fíc fiilinin mastarıdır. İlk âyetteki bu kelimeyle, kıyametin kopuşu esnasında güneşin dürüleceğine işaret edilmektedir. Güneşin

8 Bu konudaki eserlere şunlar örnek verilebilir: Muhammed Zağlûl en-Neccâr, Kadiyyetü'l-i்'cazi'l-ïlmî (Amman: Cem'iyyetü'l-Muhafaza 'ala'l-Kur'âni'l-Kerîm, 2005), 74-78; Yusuf el-Karadâvî, Kur'ân'ı Anlamada Yöntem, çev. M. Nurullah Aktaş (İstanbul: Nida Yayınları, 2015), 448-462; Güllüce, Bilimsel Tefsirde Usûl, 96-111; Cüneyt Eren, "Bilimsel Tefsir Metodolojisi", İslami İlimlerde Metodoloji/Usûl Meselesi, ed. İsmail Kurt - S. Ali Tüz (İstanbul: Ensar Neşriyat, 2005), 570-571; Ahmet Akbaş, “Kur'ân Nassının Bilimsel Veriler Işı̆̆ı̆nda Yorumlanmasının İmkân ve Sınırları", İslam ve Yorum ed. Fikret Karaman (Malatya: Malatya İlahiyat Vakfı Yayınları, 2017), 2/111-151; Abdullah Temizkan, "Bilimsel Tefsire Farklı Bir Yaklaşım: Zağlûl Neccâr Örneği", e-Şarkiyat İlmi Araştırmalar Dergisi 10/1(19) (2018), 39-67. 
246 | A. AKBAŞ / Tekvîr Sûresi'ndeki “Hunnes", "Cevâri” ve "Künnes” Kelimeleri Bağlamında Bir Bilimsel Tefsir Denemesi

dürülmesi, yıldızların sönmesi, dağların yürütülmesi, on aylık gebe develerin dahi başıboş bırakılması gibi kıyamet gerçekleşirken yaşanacak bazı olaylara işaretle başlayan sûrenin ilk bölümü, nihayetinde her insanın, dünyada yaptıklarının karşılığını göreceği gerçeğine işaret eden 14. âyetle son bulmaktadır. 15. âyetten itibaren bazı olgular üzerine yemin edilerek Kur'ân'ın, vahiy meleğinin ilettiği ilahi sözler olduğu, Hz. Muhammed (s.a.s.)'in kendi sözleri olmadığ hakikati vurgulanmakta ve insanlar, iyi düşünüp kendilerine gelmeleri için uyarılmaktadırlar. Sûrenin ilk bölümünde "kıyamet", ikinci bölümünde ise "risâlet" olmak üzere İslam inancının iki esası üzerinde durulmaktadır. ${ }^{9}$

Bu çalışmada ele alacağımız 15-16. âyetler, risâlet hakikatine yani Hz. Muhammed (s.a.s.)'in Allah tarafından gönderilmiş bir elçi ve tebliğ ettiği sözlerin de Allah kelâmı olduğuna işaret etmek üzere evrendeki bazı kozmik hakikatlere kasem (yemin) edilmesiyle başlayan ikinci kısmın ilk âyetleridir. Bu kısımda, "hunnes", "cevârî" ve "künnes"e, peşi sıra ise karanlığı iyice çöken geceye ve ağarıp nefes almaya başlayan sabaha yemin edilmekte, bu yeminlerin cevabı olarak da "Kesinlikle bu, çok değerli bir elçinin getirdiği sözlerdir" denilerek Kur'ân'ın Allah kelâmı oluşu güçlü bir şekilde vurgulanmaktadır.

Tahlili

2. Tekvîr Sûresi 15-16. Âyetlerin Metin ve Mana Açısından

Tekvîr Sûresi'nin 15-16. âyetlerinin Arapça metni şöyledir:

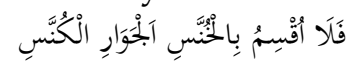

Burada, üç kelime ile tavsif edilen bir olguya yemin edilmektedir. Bu kelimelerle neyin kastedildiği açık olmadığından Türkçe meâllerde de farklı tercihler söz konusu olmuştur. Aşağıdaki meâllerde bu durum görülmektedir: ${ }^{10}$ İşl. Bşk.)

"Andolsun, bir görünüp bir sinenlere, akıp gidip kaybolanlara." (Diyanet

\footnotetext{
9 Abdurrahman Hasan Habenneke el-Meydânî, Me'âricu't-Tefekkür ve Dekaiku'tTedebbür (Dımaşk: Dâru'l-Kalem, 2000), 1/397-398; Ebü'l-A'lâ Mevdûdî, Tefhîmu'lKur'ân, çev. Muhammed Han Kayani vd. (İstanbul: İnsan Yayınları, 1996), 7/47; Hayrettin Karaman vd., Kur'ân Yolu (Ankara: Diyanet İşleri Başkanlığı Yayınları, 2014) 5/559.

10 Bu meâller, Hasenat Kur'ân Araştırma Sistemi 4.0'dan alınmıştır.
} 
A. AKBAŞ / An Essay on the Scientific Tafsir in the Context of the Words "Hunnes", "Cevâri" and

"Kûnnes" from Surah at-Takwir I 247

"Hayır! Akıp giden, bir kaybolup bir etrafi aydinlatan yıldizlara andolsun." (T. Diyanet Vakfi)

"Artık andolsun geri dönen yıldizlara. Akıp saklaniveren (seyyare)lere." (Ö.N. Bilmen)

"Şimdi kasem ederim o sinenlere, o akıp akıp yuvasina girenlere." (Elmalılı M. H. Yazır)

"(Demek ki hakikat, ey kâfirler, sizin dediğiniz gibi değildir). Andederim o (geceleri) geri dön(üp aydınlık neşr eden), akıp akıp yuvalarına giden (yıldı)lara." (H.B. Çantay)

"Hayır, iş onların sandı̆̆ı gibi değil! Yemin olsun o sinip gizlenenlere, akıp akıp giderek yuvasına girenlere." (Y.N. Öztürk)

"Yoo, yemin ederim o geri kalıp gizlenenlere; akıp gidenlere, dönüp saklananlara." (S. Ateş)

"Hayır! Hayır! Dönüp duran yıldızları tanıklı̆̆a çă̆ırırım, yörüngelerinde akan ve kaybolan gezegenleri." (M. Esed)

"Hayır! Hayır! Yörüngelerinde akıp giderek doğan ve batan yıldızlara andolsun!" (Kur'ân Yolu Tefsiri) ${ }^{11}$

"Gündüzleri kaybolup geceleri ortaya çıkan yıldızlara andiçerim ki..." (Salih Akdemir) ${ }^{12}$

Görüldüğü gibi meâllerde, söz konusu kelimelerle ilgili birbirinden farklı ifadeler kullanılmıştır. Bununla beraber nihayetinde bu âyetlerde, çoğul formundaki üç kelime ile ifade edilen bir veya birkaç olguya güçlü bir şekilde yemin edilmekte olduğu açıktır. Bu nedenle burada, öncelikle Kur'ân'daki kasemler arasından, bu âyetlerde kullanılan " لأُ أُقْسِمْ (lâ uksimu) kasemi üzerinde durmamız, akabinde ise bu üç kelimenin Arap dili açısından tahlilini yapmamız gerekmektedir.

\subsection{Bir Kasem Çeşidi Olarak "lâ uksimu” Tabiri}

Kasem, "yemin" anlamina gelen bir kelime olup çoğulu "أقُّام" şeklinde gelir. Kelimenin fiil formu, "yemin etti" anlaminda "قأقسَتَ" "إنَ" şeklinde olup bu fiil "bâ" harfiyle geçişli kılınmaktadır. Kasem, kendisiyle bir haberin tekit edildiği cümle olup tekit eden ifadeye "muksamün bih", tekit edilen şeye ise "muksamün aleyh" denir. ${ }^{13}$

11 Karaman vd., Kur'ân Yolu, 5/561.

12 Salih Akdemir, Son Çağrı Kur'ân (Ankara: Ankara Okulu Yayınları, 2015), 585.

13 Halil b. Ahmed el-Ferâhidî, Kitabu'l-'Ayn (Beyrut: Dâru'l-Kütübi'l-İlmiyye, 2003), “Ksm”, 3/389; Ebû Mansur Muhammed b. Ahmed el Ezherî, Tehzî̉ül-Lüğa (Misır: elMüessetü'l-Mısriyyetü'l-'Âmme, 1964), “Ksm”, 8/420; Abdurrahman Ensari, el- 
248 | A. AKBAŞ / Tekvîr Sûresi'ndeki “Hunnes", "Cevâri” ve "Künnes” Kelimeleri Bağlamında Bir Bilimsel Tefsir Denemesi

Kasem yöntemiyle sözü pekiştirme, vurgulama ve muhatabı etkileyip ikna etme hedeflenir. ${ }^{14}$

Kur'ân'da birçok farklı üslûp ve tarzda yemin ifadeleri kullanılmıştır. Bir şey üzerine yemin etmek, nüzul dönemi Arap kültüründe çok sık başvurulan bir üslûp olup Kur'ân'da da çokça kullanılmış, Kur'ân ilimlerine dair eserlerde bu konu "Aksâmu'lKur'ân" başlığı altında özel olarak ele alınmıştır. ${ }^{15}$ Kur'ân'da sarih ve gayr-1 sarih olmak üzere 84 sûrede 460 'tan fazla kasem mevcut olup bunların 350'si Mekkî sûrelerdedir. ${ }^{16}$ Kur'ân'daki kasemlerin gayeleri hakkındaki görüşler özetle şöyledir:17

a. Kur'an, ilk muhatapları olan Arap toplumuna, alışık oldukları üslûp ile hitap etmeyi amaçlamıştır.

b. Yemin ifadelerinin kullanıldığı âyetlerde bahse konu olan hususlar bu üslûp ile vurgulanarak pekiştirilmiştir.

c. Yemin ifadeleriyle, yemin edilen varlık veya olayların önemine işaret edilmiş, insanların onlar üzerinde iyice düşünmeleri amaçlanmıştır. ${ }^{18}$

Konumuz olan âyetlerin başında geçen "lâ uksimu" kasemi ise üslûp itibariyle diğer kasemlerden farklıdır. Zira kasem ifadesinin başına nefiy (olumsuzluk) edatı olan "lâ"nın gelmesiyle "yemin

Mürşidü'l-Vecîz ilâ 'Ulûmi'l-Kur'âni'l-Azîz (İstanbul: Nida Yayınları, 2016), 219-221; Abdulbaki Turan, “Kur'ân-1 Kerîm'de Yeminler (Aksâmu'l-Kur'ân)”, Selçuk Üniversitesi İlahiyat Fakültesi Dergisi 2/2 (1986), 97.

14 Ertuğrul Boynukalın, "Yemin", Türkiye Diyanet Vakfı İslâm Ansiklopedisi (Ankara: TDV Yayınları, 2013), 43/417; Şükrü Aydın, “Kur'ân'daki Yeminlerde (Aksamu'l-Kur'ân) Çeviri/Anlama Problemi ve Alternatif Muhammed Esed Çevirisi", Uluslararası Sosyal Araştırmalar Dergisi 9/46 (2016), 918.

15 Cerrahoğlu, Tefsir Usûlü, 168-170; Turan, “Kur'ân-1 Kerîm'de Yeminler (Aksâmu'1Kur'ân)", 98-100; Celal Kırca, "Aksâmu'l-Kur'ân", Türkiye Diyanet Vakfi İslâm Ansiklopedisi (Ankara: TDV Yayınları, 1989), 2/290; Muhammed Coşkun, "Aksâmu'1Kur'ân: 89/Fecr, 1-14. Âyetleri Örneğinde Yemin İfadelerinin Anlaşılması ve Tercüme Edilmesi", Marmara Üniversitesi İlahiyat Fakültesi Dergisi 46 (2014), 40-42.

16 Turan, "Kur'ân-1 Kerîm'de Yeminler (Aksâmu'l-Kur'ân)", 112.

${ }_{17} \mathrm{Bu}$ konuda geniş bilgi için bk. Abdurrahman Hasan Habenneke el-Meydanî, Kavaidü't-Tedebbüri'l-Emsel li Kitabillahi Azze ve Cell (Dımaşk: Dâru'l-Kalem, 2009), 472-476.

18 Coşkun, "Aksâmu'l-Kur'ân", 42-43; Kutbettin Ekinci, "Kur'ân'da Allah'ın Zatı Dışında Kullanılan Yeminleri Sözün Maksadı Açısından Anlamak", Ankara Üniversitesi Illahiyat Fakültesi Dergisi 57/1 (2016), 100. 
etmiyorum" gibi bir anlam söz konusu olmaktadır. Ancak ilgili eserlerde bu ifadenin bu anlama gelmediği, nefiy edatının burada farklı bir amaç için kullanıldığı ve bu şekildeki bir kullanımın Arap kültüründe de mevcut olduğu, "lâ uksimu" ifadesinin her halükârda "yemin ediyorum" anlamina geldiği belirtilmektedir. ${ }^{19}$ Baştaki nefiy edatının amacı ise muhataplara karşı, onların iddia ve fikirlerinin yanlış olduğunu, işin hiç de onların düşündükleri gibi olmadığını vurgulamaktır. Bu meyanda buradaki "lâ", "Hayır! İş hiç de sizin dediğiniz gibi değil! Hayır, asla! Öyle değil!" gibi anlamlara gelmekte, peşinden gelen "uksimu" ifadesiyle de "Yemin olsun ki hakikat şöyledir" denmektedir. Böylece "lâ uksimu" şeklindeki bu kullanımda öncelikle muhataplardaki yanlışlar, batıl fikirler ve inançlar reddedilmekte, akabinde ise hakikat güçlü bir kasemle vurgulanmaktadır. ${ }^{20}$ Yukarıda vermiş olduğumuz bazı meâllerde bu anlamin vurgulandığı görülmektedir. ${ }^{21}$

Mâverdî, kasemin başına gelen "lâ"nın kullanım amacı hakkında şu üç görüşü zikretmektedir:

a. Buradaki "lâ" sıladır, yani geçiş için kullanılan bir edattır. Şu beyitte bu kullanım görülebilir:

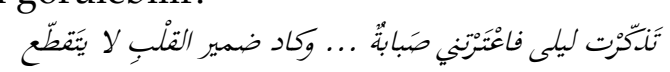

"Leyla'yı hatırladım da aşk kuşattı dört bir yanımı ve kalbimin içi neredeyse, hayır hayır, paramparça olacaktı."

b. Buradaki "lâ" tekit yani sözü vurgulamak için gelmiştir. Buna İmruu'l-Kays'in şu beyti örnektir:

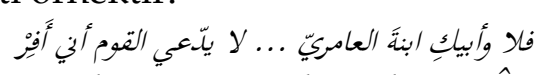

"Hayır, hayır, baban adına yemin olsun ki ey Âmirî'nin kızı, kavim benim kaçacağımı asla iddia etmez."

19 Ferâhidî, “Ksm”, 3/389; Coşkun, “Aksâmu'l-Kur'ân”, 46.

20 Ebû Muhammed Abdulhakk b. Ğâlib İbn Atiyye el-Endelüsî, el-Muharraru'l-Vecîz fî Tefsîri'l-Kitâbi'l-'Azîz (Beyrut: Dâru'l-Kütübi'l-'İlmiyye, 1422 h.), 5/443; Kırca, “Aksâmu'l-Kur'ân", 2/290; Coşkun, “Aksâmu'l-Kur'ân”, 46. Bu konuda daha tafsilatlı bir değerlendirme için bk. Mustafa Çalışkan, Kur'ân Dilinde Kasem (Yemin) Üslûbu (Adana: Çukurova Üniversitesi, Sosyal Bilimler Enstitüsü, Doktora Tezi, 2016), 58-63.

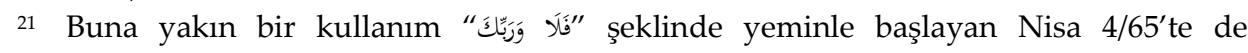
mevcuttur. 
250 | A. AKBAŞ / Tekvîr Sûresi'ndeki "Hunnes", "Cevâri” ve "Künnes” Kelimeleri Bağlamında Bir Bilimsel Tefsir Denemesi

c. Âyetlerde kasemin başına gelen "lâ" daha öncesinde geçen müşriklere ait bir söze yapılmış bir reddiyedir. ${ }^{22}$

Kasemin "lâ uksimu” şeklindeki bu kullanımı, Kur'ân'da sekiz âyette geçmektedir. Bu âyetlerde, yıldızların mevkileri, ${ }^{23}$ gördügünüz ve göremediğiniz şeyler, ${ }^{24}$ doğuların ve batıların rabbi, ${ }^{25}$ kıyamet günü, ${ }^{26}$ çok kınayan/pişman olan nefis, ${ }^{27}$ hunnes ve künnes, ${ }^{28}$ şafak $^{29}$ ve emin belde $^{30}$ gibi farklı unsurlara yemin edilmektedir. Bu âyetlerin geçtiği sûrelerin tamamı Mekkîdir. ${ }^{31}$

\subsection{Hunnes, Cevârî ve Künnes Kelimelerinin Tahlili}

\subsubsection{Hunnes (خنّس)}

"Hunnes" kelimesi, çoğul formunda olup tekili, ism-i fail formundaki "hânis" veya "hânise" kelimesidir. Kelimenin kökü olan "hunûs" ve "hans" mastarlarının temel anlamı "geri çekilme, büzülme,

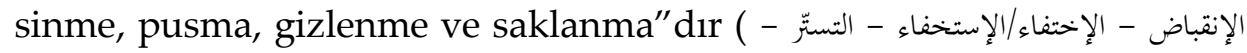
الإنكماش). Bu nedenle "hânis", "geri çekilen, büzülen, pusan, sinen, gizlenen ve saklanan" anlamlarına gelmekte olup "hunnes" ise onun çoğuludur. Kur'ân'da bu kökten türemiş olan sadece iki kelime mevcut olup biri buradaki "hunnes" kelimesi diğeri de Nâs Sûresi'nde, vesvese veren şeytan hakkında kullanılan "hannâs" kelimesidir. ${ }^{32}$ Sözlüklerde şeytan için bu kelimenin kullanılmasının nedeni olarak "Allah'ın adı zikredildiğinde geri çekilip sinmesi" zikredilmektedir. Aynı kökten türemiş olan ve Arap toplumu tarafından çokça kullanılan bir kelime de burnun şekline işaret eden "ahnes" olup dişil formu "hansâ"dır. Her iki kelimenin de çoğulu "huns" şeklinde gelir. "Ahnes", "yassı ve basık burunlu" demek olup burnun ucunun, burun deliklerinden daha

22 Ebü'l-Hasan Ali b. Muhammed b. Habîb el-Mâverdî, en-Nüketü ve'l-'Uyûn (Beyrut: Dâru'l-Kütübi'l-'İlmiyye, ts.), 6/150-151.

23 el-Vâkı 56/75.

24 el-Hakka 69/38.

25 el-Meâric 70/40.

26 el-Kiyamet 75/1.

27 el-Kiyamet 75/2.

28 et-Tekvîr 81/15-16.

29 el-İnşikak 84/16.

30 el-Beled 90/1.

31 Âişe Abdurrahman Bintü'ş-Şâti, et-Tefsîru'l-Beyân̂̂ li'l-Kur'âni'l-Kerîm (Kahire: Dâru'lMeârif, ts.), $1 / 165$.

32 en-Nâs 114/4. 
yukarıda ve yüze doğru basık, kısa ve belirsiz olması, burun deliklerinin ise yayvan, dudaktan uzak, yüze doğru yapışık ve basık olması için kullanılan bir kelimedir. Yani burun ileri doğru uzamamış adeta geriye doğru çekilmiş, neredeyse yüzle birleşip belirsiz bir hal alarak gizlenmiştir. Araplar "yassı ve düz burunlu" olan inek, antilop vb. hayvanlar hatta aslanlar için "huns" kelimesini kullanmışlardır. Özetle, İbn Fâris'in de belirttiği gibi “h-n-s" kökünden türemiş bütün kelimeler anlam olarak aynı asla rücu ederler ki o da "gizlenme ve saklanma", bir başka ifade ile görünür ve belirgin olmamadır. ${ }^{33}$

\subsubsection{Cevârî (جواري)}

"Cevârî" kelimesi ism-i fail formundaki "câriye" kelimesinin çoğuludur. Âyette tahfif için "cevârî" kelimesinin sonundaki "yâ" harfi düşmüştür. ${ }^{34}$ Kelimenin kökü "cery" veya "cereyân" olup aslen "akmak, hızlıca geçip gitmek" anlamlarına gelmekte, rüzgârın, suyun, güneşin vb. akıp gitmesi hatta atın koşması için kullanılmaktadır. Denizde akıp giden veya gökyüzünde hareket eden güneş için "câriye" kelimesi kullanılmaktadır. ${ }^{35} \mathrm{Bu}$ durumda âyetteki "cevârî" kelimesi "akanlar, hızlıca geçip gidenler" anlamına gelmektedir.

Kur'ân'da "cery" kökünden türemiş olan ve "akmakta, akıyor" anlamina gelen "yecrî, tecrî" vb. kelimeler elli yedi âyette geçmekte, bunların çoğu nehir ve pınarların akması, bir kısmı ise rüzgârın, gemilerin ve güneşin akıp gitmesi için kullanılmaktadır. Üç âyette

33 Ferâhidî, “Hns”, 1/447-448; Ebû Yusuf Yakub b. İshak b. Sikkît, el-Kenzü'l-Lüğavî (Kahire: Mektebetü'l-Mütenebbî, ts.), "Hns", 1/190; Ebû Muhammed Abdullah b. Müslim b. Kuteybe ed-Dîneverî, Kitâbu'l-Cerâsîm (Dımaşk: Vizâretü's-Sekafe, ts.), "Hns", 1/175; Ebû Bekr Muhammed b. el-Hasan b. Düreyd, Cemheretü'l-Lü̆̆a (Beyrut: Dâru'l-İlmi li'l-Melâyîn, 1987), “Hns", 599; Ezherî, "Hns", 7/173; İsmail b. Hammad el-Cevherî, es-Sihâh (Beyrut: Dâru'l-İlmi li'l-Melâyîn, 1990), "Hns", 925; Ebü'l-Hüseyn Ahmed b. Fâris, Mu'cemu Mekayîsi'l-Luğa (Dımaşk: Dâru'l-Fikr, 1979) “Hns", 2/223; Ebü'l-Kasım el-Hüseyn b. Muhammed Râgıb el-İsfahânî, Mu'cemu Müfredâti Elfâzi'lKur'ân (Beyrut: Dâru'l-Kütübi'l-i̇lmiyye, 1997), “Hns", 159; Ebü'l-Fadl Cemâlüddin Muhammed b. Mükerrem b. Ali b. Ahmed İbn Manzûr, Lisânu'l-'Arab (Kahire: Dâru'l-Meârif, 1981), “Hns”, 15/1276-1277.

34 Ebû Cafer Ahmed b. Muhammed en-Nehhâs, I'râbu'l-Kur'ân (Beyrut: Dâru'lKütübi'l-İlmiyye, 1421 h.), 5/101; Habenneke, Me'âricu't-Tefekkür, 1/421.

35 Ferâhidî, "Cry", 1/237; İbn Düreyd, "Cry”, 469; Ezherî, "Cry”, 11/172-173; Cevherî, “Cry”, 6/2301; İbn Fâris, “Cry”, 1/448; İsfahânî, “Cry”, 92; İbn Manzûr, “Cry”, 6/610. 
252 I A. AKBAŞ / Tekvîr Sûresi'ndeki "Hunnes", "Cevâri” ve "Künnes" Kelimeleri Bağlamında Bir Bilimsel Tefsir Denemesi

"câriye" ve "cevârî" kelimeleri ile gemilere işaret edilmekte, ${ }^{36}$ bir âyette ise geminin akıp gitmesi hakkında "mecrâ" kelimesi mimli mastar olarak zikredilmektedir. ${ }^{37}$

\subsubsection{Künnes (كنّس)}

"Künnes" kelimesi, çoğul formunda olup tekili, ism-i fail formundaki "kânis" veya "kânise" kelimesidir. Kelimenin kökü olan "künûs" ve "kens" mastarlarının temel anlamlarını hicri ilk asırlarda yazılmış olan kamuslarda araştırdığımızda karşımıza iki anlam çıkmaktadır. Bu anlamlardan biri, Halil b. Ahmed el-Ferâhidî'nin ilk

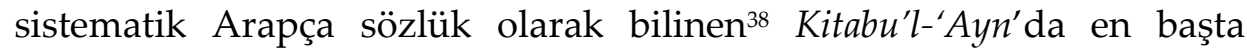
zikrettiği anlam olan "كسح القمام عن وجه الأرض yani "çer çöpü yerden süpürüp toplamak" şeklindeki anlamdır. İbn Fâris'in kelimenin ilk anlamina dair kullandığ1 ifade Ferâhidî'ninkine benzer bir şekilde " سَفْرِ

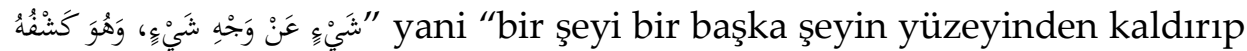
izale etmek, üstünü açmak" ifadesidir. "Künûs" kelimesinin, "süpürmek, bir yüzeyin üstündeki şeyleri izale edip üstünü açmak" şeklindeki anlamı, diğer önemli kamuslarda da öncelikle zikredilen

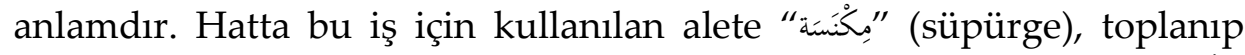
izale edilen çer-çöpe (süprüntüye) ve bunların yığıldiğı yere ise "کُنَّ" denir. "Evi süpürdüm, yerdeki çer-çöpü, toz-toprağı izale ettim" anlamında "كَنَسْتُ البَيْتَ iflesi kullanılır. Bir kavme saldırıp onları kırıp

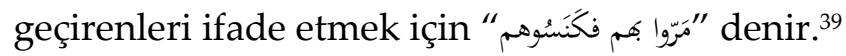

36 Kur'ân'da "gemi" anlamında kullanılan "câriye" kelimesi hakkındaki özel bir araştırma için bk. Güllüce, "Rahman Sûresi 24. Âyetteki el-Cevârî Kelimesi Hakkında Farklı Bir Yorum ve Değerlendirmesi", Ekev Akademi Dergisi 1/4 (1999), 123-134.

37 Muhammed Fuâd Abdulbâkî, el-Mu'cemu'l-Müfehres li-Elfâzi'l-Kur'âni'l-Kerîm (Kahire, Dâru'l-Hadîs, ts.), “Cry”, 167-168.

38 Tevfik Rüştü Topuzoğlu, "Halil b. Ahmed", Türkiye Diyanet Vakfı İslâm Ansiklopedisi (Ankara: TDV Yayınları, 1997), 15/309-311.

39 Ferâhidî, "Kns", 1/447-448; İbn Kuteybe, "Kns", 1/417; Ebû Hilal, "Kns”, 1/291; İbn Düreyd, "Kns", 856; Ezherî, "Kns", 10/63; Cevherî, “Kns", 971-972; İbn Fâris, "Kns", 5/636; Ebü'l-Kasım Cârullah Mahmud b. Ömer ez-Zemahşerî, Esâsü'l-Belâğa (Beyrut: Dâru'l-Kütübi'l-i̇lmiyye, 1998), "Kns", 2/148; İ̉n Manzûr, "Kns", 44/3938; Muhibbuddin Ebü'l-Feyz Muhammed Murtaza el-Hüseynî ez-Zebîdî, Tâcu'l-'Arûs min Cevâhiri'l-Kamûs (Kuveyt: Matbaatu Hukûmeti'l-Kuveyt, 1965), “Kns”, 16/452453. 
"Künûs" mastarına verilen ikinci temel anlam ise geyik, ceylan ve antilop ${ }^{40}$ türü hayvanların, otların ve dalların arasına veya yuvalarına girip saklanmaları ile ilgilidir. Sıcaktan veya soğuktan korunmak amacıyla bu hayvanların bir yere girip sığınmalarını ifade etmek üzere

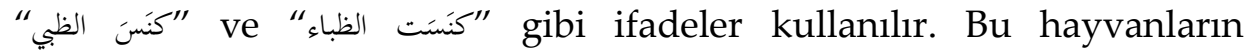

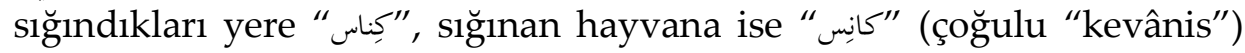
denir. " kelimesi ise kilise anlamına gelmektedir. ${ }^{41}$ Kilise için "kenîse" denmesi, muhtemelen İslam'daki "câmi" kelimesinde olduğu gibi "ibadet amaciyla girilen/toplanılan yer" olması nedeniyledir.

Kur'ân'da "künnes" ile aynı kökten türemiş olan başka bir kelime bulunmamaktadır. Kanaatimizce "künûs" kökünden türemiş olan kelimelerin Arapçada hem "süpürüp temizleme, çer-çöpü toparlayıp izale etme" hem de "yuvaya girme, dalların arasina gizlenme" anlamlarında kullanılmış olması, bu iki anlam arasında bir bağ olmasından kaynaklanmaktadır. Bu anlamsal bağa işaret etmek üzere İbn Düreyd, "Geyiğin yuvası hakkındaki kullanımı da süpürüp temizleme anlamından türemiştir. Zira yuvasına giren hayvan da toprağın serinliğine ulaşmak için yerdeki kumu eşeleyip temizler" demektedir. ${ }^{42}$ Bu durumda yuva anlamındaki "kinâs" ifadesi, aslında "hayvanın eşeleyip temizlediği yer" manasına gelmektedir. Bu da bize kelimenin asli anlamının "bir yere girme, sığınma veya saklanma" değil, kamuslarda dikkat çekildiği gibi "bir yeri süpürüp temizleme, çer-çöp veya toz toprak gibi nesneleri bir yerden izale edip bir başka yere yığma" olduğunu göstermektedir.

Arapçayı konuşan toplumların nesilden nesile atalarından tevarüs ettikleri bu kelimeyi, günümüzde nasıl ve ne şekillerde kullandıkları da önemlidir. "Künûs" veya "kens" kökünden türeyip günümüzde kullanılan kelimelere baktığımızda, evi, odayı veya caddeyi süpürmek

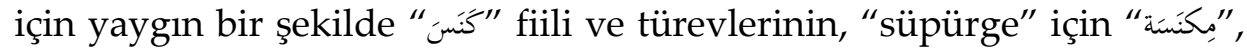

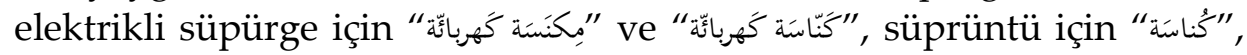

40 Bu üç tür de birbirinden farklı olmakla beraber yaban hayvanı olmaları yönüyle ortaktırlar. Bk. Güncel Türkçe Sözlük, "Geyik", "Ceylan”, “Antilop" (Erişim 06.10.2020)

41 Ferâhidî, “Kns", 1/447-448; İbn Düreyd, "Kns”, 856; Ezherî, “Kns”, 10/63; Cevherî, “Kns", 971-972; İbn Fâris, "Kns", 5/636; Zemahşerî, "Kns", 148; İbn Manzûr, "Kns", 44/3938; Zebîdî, “Kns”, 16/452-453.

42 "İbn Düreyd, “Kns”, 856. 
254 | A. AKBAŞ / Tekvîr Sûresi'ndeki “Hunnes”, “Cevâri” ve "Künnes” Kelimeleri Bağlamında Bir Bilimsel Tefsir Denemesi

mayın tespit ve temizleme cihazı için "كانِنَّة الألغام", çöpçü için " kelimelerinin kullanıldığı görülmektedir. ${ }^{43} \mathrm{Bu}$ da kelimenin toplumsal bellekteki asıl anlamının süpürüp temizleme olduğunu göstermektedir.

\section{Klasik ve Modern Tefsirlerdeki Yorumlar}

Tekvîr Sûresi 15-16. âyetlerde geçen kelimeler hakkında Arap diline dair en meşhur kamuslardan istifade ederek vermiş olduğumuz lügavi açılamaların ardından müfessirlerimizin bu âyetleri nasıl yorumladıkları üzerinde durmamız gerekmektedir. Zira kelimelerin sözlük anlamları belli olsa da âyetlerin, geçtikleri bağlam içerisinde bazen farklı yorumlanabildiği ve bu yorumlara müfessirin zihin dünyasının ve tasavvurunun etki ettiği malumdur.

Konumuz olan âyetlerde, üç kelimeyle işaret edilen bir olgu üzerine yapılan güçlü bir yemin mevcuttur. Peşi sıra ise karanlığı çöken

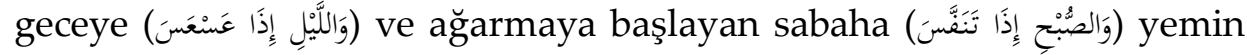
edilmekte, yeminin cevabı olarak ise Kur'ân'ın, şerefli bir elçinin sözü olduğu ifade edilmektedir. Üzerinde durduğumuz üç kelime kullanılarak kendisine yemin edilen şeyin ne olduğuna dair tefsirlerimizde birçok farklı açıklama ve yorum mevcuttur. Muksamün bih olan "hunnes, cevâri ve künnes" kelimeleri, yukarıda da ifade ettiğimiz gibi "hânise, cârîye ve kânise" kelimelerinin çoğullarıdır. Bu kelimelerle neyin kastedildiğine, yani muksamün bih'in ne olduğuna yani hakikatte neyin üzerine yemin edildiğine dair birden fazla görüş belirtmeyen müfessir neredeyse yoktur. İhtilaflı konularda kendisinden önceki tüm görüşleri bir arada zikretmesiyle bilinen müfessir Mâverdî'den nakille bu görüşler şöyle özetlenebilir:

1. Beş büyük yıldıza yemin edilmektedir. Bunlar, Zühal, Müşteri, Merih, Zühre ve Utarit yıldızlarıdır.

2. Tüm yıldızlara yemin edilmektedir.

3. Ceylan, geyik, antilop vb. yaban hayvanlarına yemin edilmektedir.

4. Meleklere yemin edilmektedir. ${ }^{44}$

Muksamün bih hakkındaki bu ihtilafın ana sebebi, âyetlerdeki üç kelimenin anlam alanıdır. Zira "hunnes"in anlamı "geri çekilenler,

43 Ahmed Muhtar Ömer, Mu'cemü'l-Lüğati'l-Arabiyyeti'l-Mu'astra (Kahire: Âlemü'lKütüb, 2008), “Kns”, 3/1962-1963; Heyet, el-Mu'cemü'l-Vesît, ed. Şevki Dayf (Kahire: Mektebetü'ş-Şürûk, 2004), “Kns”, 800.

44 Mâverdî, en-Nüketü ve'l-'Uŷ̂n, 6/216-217. 
pusanlar, sinenler, gizlenenler" veya "yassı ve basık burunlu olanlar"; "cevârî'nin anlamı "hareket edenler, akanlar, hızlıca geçip gidenler"; "künnes" in anlamı ise "süpürenler, temizleyenler" veya "yuvasına girip saklananlar" olunca tüm bu anlamlar, üzerine yemin edilen şeylerin, geyik ve antilop gibi hayvanlar veya aynı vasıflara sahip olan yıldızlar olabileceği fikrinin ortaya çıkmasına neden olmuştur. Muksamün bih'in yıldızlar olduğu iddiası, kelimelerin asli anlamlarıyla doğrudan bağlantılı olmasa da istiare yöntemiyle hayvanların vasıflarının, onlarla aynı vasıflara sahip olan yıldızlar hakkında kullanılmış olduğu görüşüne dayandırılmaktadır. Zira müfessirlere göre yıldızlar da gece görünüp gündüz gizlenmekte, aynı zamanda hareket etmekte ve yuvasına dönen hayvanlar gibi burçlarına dönmektedirler..$^{45}$

Konumuz olan âyetlerin hemen ardından gece ve sabahtan bahsedilmiş olması, müfessirlerin ekseriyetini, muksamün bih'in yıldızlar olduğu görüşünü tercihe sevk etmiş olsa da Taberî, hayvanlara mı yıldızlara mı kasem edildiği konusunda kesin bir kanıya varmayı doğru bulmamış, her iki ihtimalin de mümkün olabileceğini ve Allah'ın dilediği varlığa yemin edebileceğini savunmuştur. Onun yapmış olduğu açıklamalar, iki ihtimal arasında kaldığını ve kesin bir tercihte bulunamadığını göstermektedir. Üzerine kasem edilen şeylerin ne olduğuna dair görüşleri ve bu görüş sahiplerinden gelen rivayetleri uzun uzadiya veren Taberî'nin bu husustaki nihai kanaati şöyle özetlenebilir: Bu âyetlerle ilgili olarak söylenmesi gereken en doğru söz şudur: Allah burada, bazen gizlenen, bazen gezip dolaşan, bazen de yuvasına dönen bazı varlıklara yemin etmiştir. Hayvanların yuvasına dönmesi olayından istiare ile yıldızların yuvasına dönmesinden bahsedilmiş olması da gayet tabidir. Ancak ayetin ifadesinde, ne yaban hayvanların bırakıp yıldızları tercih etmemize, ne de yıldızları bırakıp yaban hayvanların tercih etmemize delalet edecek sarih bir delil bulunmadığı için ifadeyi umumi kabul etmemiz ve zikredilen vasıflara bakarak, mümeyyiz vasfı bazen gizlenmek bazen gezip dolaşmak ve bazen de yuvasına dönmek olan şeylere yemin edildiğini söylememiz en doğru olandır. ${ }^{46}$

45 Nehhâs, İrabu'l-Kur'ân, 5/101-102; İbn Atiyye, el-Muharraru'l-Vecîz, 5/443; Ebû Cafer Muhammed b. Cerîr et-Taberî, Câmi 'u'l-Beyân 'an Te'vili Âyi'l-Kur'ân (by.: Müessetü'rRisâle, 2000), 24/251-255.

46 Taberi, Câmi' 'u'l-Beyân, 24/251-255. 
256 | A. AKBAŞ / Tekvîr Sûresi'ndeki "Hunnes", "Cevâri” ve "Künnes” Kelimeleri Bağlamında Bir Bilimsel Tefsir Denemesi

Dilci yönüyle öne çıkan ve yukarıda lügavi açılamalarını verdiğimiz âlimler ise bu kelimeler Arap toplumunda her ne kadar bazı yaban hayvanları için kullanılmış olsa da burada yıldızların -özellikle beş yıldızın- kastedilmiş olduğunu, zira onların da kendi mecralarında hareket ederken gâh görünüp gâh gizlendiklerini, hareketlerinin yaban hayvanlarının davranışlarını andırdığını savunmuşlardır..$^{47}$ Ebû Ubeyde ise bu üç kelime hakkında "Bunlar yıldızlardır" ifadesi dışında başka hiçbir açıklama yapmamıştır. ${ }^{48}$

Matürîdî, bu âyetlerin tefsirinde öncelikle Kur'ân'daki kasemlerin maksadına değinmiş, bu tür kasemlerle Hz. Peygamber'in risâleti hususundaki şüphelerin izalesi, tevhidin, risâletin ve yeniden dirilişin de ispatının amaçlandığını, ister latif ve dakik ister kesif ve ğaliz olsun her neye kasem edilmişse, kasem edilen şeyin bu amaca hizmet ettiğini ifade etmiştir. Onun bu açılamaları, bu âyetlerde yıldızlara değil de yabani hayvanlara kasem edildiği fikrinde olanların hor görülmemesini sağlamaya yönelik giriş cümleleri gibi görünmektedir. Zira söze hazırlık meyanındaki bu açıklamaların ardından yıldızlara kasem edildiğine ve buradaki teşbih yönlerine dair görüşleri detaylı bir şekilde vermiş, son olarak İbn Mes'ud'un insandan kaçan yabani hayvanlara kasem edildiğine dair sözünü zikredip şöyle demiştir: "Her neye kasem edilmiş olursa olsun, hepsi de yukarıda zikrettiğimiz amaçlara delalet etmektedir." 49

Tefsirlerimizin birçoğunda bu âyetlere dair sahabe ve tabiinin farklı tercihleri zikredilmektedir. İbn Abbas'ın, “Hunnes, keçiler, künnes ise geyiklerdir", İbn Mes'ud'un "Bunlar antiloplardır", Hz. Ali'nin ise "Bunlar yıldızlardır" şeklindeki sözleri nakledilmekte, bazılarına göre beş yıldızın, Hasan-1 Basrî ve Katade'ye göre tüm yıldızların, Nehaî ve Câbir b. Zeyd ve bir kısım müfessirlere göre antilobun, Said b. Cübeyr ve Dahhâk'a göre ise geyiklerin kastedildiği ifade edilmektedir. Kimi

47 Ebû Zekeriyya Yahya b. Ziyâd el-Ferrâ, Meâni'l-Kur'ân (Mısır: Dâru'l-Misriye, ts.), 3/242; Ebû İshak İbrahim b. es-Seriyy ez-Zeccâc, Me'âni'l-Kur'ân (Beyrut: Âlemü'lKütüb, 1988), 5/292.

48 Ebû Ubeyde Ma'mer b. el-Müsennâ, Mecâzü'l-Kur'ân (Kahire: Mektebetü'l-Hancî, 1381 h.), 2/287.

49 Muhammed b. Muhammed b. Mahmûd Ebû Mansur el-Mâtürîdî, Te'vilâtü Ehli'sSünne (Beyrut: Dâru'l-Kütübi'l-İlmiyye, 2005), 10/434-435. 
müfessirler farklı görüşleri aktarmakla yetinmiş, çoğunluk ise açıkça yıldızların kastedildiği görüşünü tercih etmiştir. ${ }^{50}$

Zemahşerî, "hunnes" kelimesini yıldızların hareket edip sonra yine kendi burçlarına dönmesi şeklinde tefsir etmiş, "cevârî" kelimesini, hareket eden gezegenlere, "künnes" $i$ ise "yabani hayvanın yuvasına gizlenmesi gibi gizlenen" manasına hamletmiş ve burada kastedilenin beş yıldız olduğunu, güneş ve ayla birlikte hareket ettiklerini, "hunûs"un geri yerlerine dönmeleri, "künûs"un ise gündüz gizlenmeleri olduğunu, bir görüşe göre de burada tüm yıldızların kastedildiğini ifade etmiştir. ${ }^{51}$

Râzî ise bu âyetlerin tefsirindeki tüm ihtilaflara detaylı bir şekilde değinmiştir. Bu konudaki açılamaları şöyle özetlenebilir:

Burada kastedilenler hakkında iki görüş mevcuttur: Birinci Görüş: Meşhur ve zahir olan görüşe göre burada kastedilenler yıldızlardır. "Hunûs", pusma, sinme, geri çekilme (الإنقباض) ve gizlenmedir (الإستخفاء). Şeytana "hennâs" denmesi bundandır; Allah zikredilince geri çekilir, pusar. "Künûs" da yuvasına saklanmak, bir yere girip gizlenmektir. Yuvasına sığınan geyik gibi, bir kalabalığa sokuşup saklanan veya deve üstündeki hevdece giren kadın için de kullanılır. Ancak bu görüş sahipleri hangi yıldızların kastedildiği konusunda ihtilaf etmişlerdir. Zahir olan bunun beş yıldız olduğudur. Hiç şüphesiz yıldızların burada bahsedilen bu geri çekilme, akıp gitme ve gizlenme özelliklerine yemin

50 Ebü'l-Leys Nasr b. Muhammed b. Ahmed es-Semerkandî, Bahru'l-'Ulûm (Beyrut: Dâru'l-Kütübi'l-İlmiyye, 1993), 3/552; Ebû Muhammed el-Hüseyn b. Mes'ûd elBeğavî, Méâlimu't-Tenzîl (Beyrut: Dâru İhyâi't-Türâsi'l-'Arabî, 1420 h.), 5/217; İ̉n 'Atiyye, el-Muharraru'l-Vecîz, 5/443; Ebü'l-Ferec Cemâlüddin Abdurrahman b. Ali b. Muhammed İbnü'l-Cevzî, Zâdu'l-Mesîr fì 'İlmi't-Tefsîr (Beyrut: Dâru'l-Kitabi'l-'Arabî, 1422 h.), 4/407; Ahmed b. Yusuf b. Abdiddâim es-Semîn el-Halebî, ed-Dürrü'l-Mesûn fì 'Ulûmi'l-Kitabi'l-Meknûn (Dımaşk: Dâru'l-Kalem, ts.), 10/705; Ebü'l-Fidâ İsmail b. Amr b. Kesir ed-Dimaşkî, Tefsîru'l-Kur'âni'l-'Azîm (by.: Dâru Taybe, 1999), 8/336-337; Nâsıruddin Ebû Saî̀d Abdullah b. Ömer b. Muhammed eş-Şirâzî el-Beyzâvî, Envâru't-Tenzîl ve Esrâru't-Te'vîl (Beyrut: Dâru İhyâi't-Türâsi'l-'Arabî, 1418 h.), 5/290; Ebû Hayyân Muhammed b. Yusuf b. Ali el-Endelüsî, el-Bahru'l-Muhît (Beyrut: Dâru'l-Fikr, 1420 h.), 10/416-417; Ebü's-Suûd Muhammed b. Muhammed el-'İmâdî, İrşâdu'l-'Akli's-Selîm ilâ Mezâya'l-Kur'âni'l-Kerîm (Beyrut: Dâru İhyâi't-Türâsi'l-'Arabî, ts.), 9/117-118.

51 Ebü'l-Kasım Cârullah Mahmud b. Ömer ez-Zemahşerî, Tefsîru'l-Keşşâf 'an Hakaiki'tTenzîl ve 'Uyûni'l-Ekavîl fî̀ Vücûhi't-Te'vîl (Beyrut: Dâru'l-Kitabi'l-'Arabî, 1407 h.), 4/710-711. 
258 | A. AKBAŞ / Tekvîr Sûresi'ndeki “Hunnes", "Cevâri” ve "Künnes” Kelimeleri Bağlamında Bir Bilimsel Tefsir Denemesi

edilmiş olması, onlarda şaşkınlık veren ve hayret uyandıran bir hal

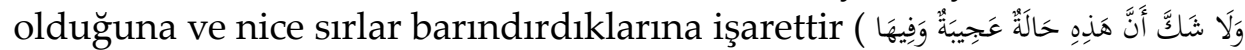
(أَسْرارُ عَظِيمَة بَاهِرَّة Hunûs onların gündüz gözle görülmemeleri, künûs ise tıpkı yabani hayvanlar gibi gece yerlerine yani yuvalarına dönmeleridir. Diğer bir görüşe göre ise doğuş ve batış yerleri sürekli değişen yedi gezegendir. En doğrusunu Allah bilir.

İkinci Görüş: Bazılarına göre ise burada kastedilenler geyik ve antilop gibi yaban hayvanlarıdır. Bu görüş, İbn Mes'ud, Nehâ̂ ve Said b. Cübeyr'den nakledilmiştir. Buna göre burada, yassı-basık burunlu olan bu hayvanların gizlenmelerine ve yuvalarına sığınmalarına yemin edilmektedir. ${ }^{52}$

Râzî, en doğru olanın ilk görüş olduğunu, yani âyetlerde yıldızlara yemin edildiğini savunmakta ve bu tercihini şöyle temellendirmektedir:

1. Bu âyetlerin devamındaki âyette karanlığı, her yeri kuşatan geceye yemin edilmektedir. Bu ifade, yabani hayvanlardan ziyade yıldızlara daha yakındır.

2. Kasem edilen şeyin daha büyük, heybetli ve azametli olması, o kasemin değerini, etkisini ve dehşetini ziyadeleştirir. Açıktır ki yıldızlar, geyik vb. yaban hayvanlarından daha üstün seviyededirler.

3. "Hunnes", "hânis"in çoğuludur. Burnun yassı ve basık olması için kullanılan müzekker formdaki "ehnes" ve müennes formdaki "hansâ" kelimelerinin çoğulu ise "hunnes" değil, "huns" şeklinde gelir. Yaban hayvanları hakkında "hunnes" kelimesinin kullanılmış olduğunu kabul etsek dahi bu, basık burunlu olmalarını kasıt için değil yuvalarına, dalların arkasına gizlenmeleri, gözlerden saklanmaları ve gizlenmeleri anlamindadır. ${ }^{53}$

Görüldügü gibi Râzî, 1srarla bu âyetlerde geyik ve antiloplara değil de yıldızlara kasem edildiğini ispata çalışmıştır. Taberî gibi ihtiyatlı ve çekimser kalmamış, net bir şekilde tercihini ve delillerini ortaya koymuştur.

Kurtubî de yukarıda mezkûr tüm görüşleri vermekle beraber özellikle sahabe ve tabiinden, burada kastedilenin antiloplar olduğuna dair rivayetlere ağırlık vermiştir. Ayrıca Kuşeyrî̀nin bu konudaki

52 Fahruddin Muhammed er-Râzî, Mefâtîhu'l-Ğayb (Beyrut: Dâru İhyâi't-Türâsi'l-'Arabî, 1420 h.), 31/67-68.

53 Râzî, Mefâtîhu'l-Ğayb, 31/68. 
açıklamalarını aktarmış ve onun, "Âyetlerin devamında gece ve sabah zikredildiği için kastın yıldızlara hamledilmesi daha sahihtir, yıldızlar zikredilmeye daha layıktır" sözüne kızarcasına şu sert ifadeleri kullanarak adeta muksamün bih'in hayvanlar olduğunu ispata çalışmıştır: "Allah, yarattıklarından canlı olsun cansız olsun dilediği şeye kasem etme hakkına sahiptir; o kasemin hikmeti bilinmese de bu böyledir." ${ }^{54}$

$\mathrm{Bu}$ âyetler üzerine detaylı açıklamalar yapanlardan birisi de İbn Kayyim el-Cevziyye'dir. Kur'ân'daki kasemleri incelediği et-Tibyân fi Aksâmi'l-Kur'ân adlı eserinde özel bir fasıl açarak bu iki âyeti ele almıştır. Âyetlerdeki üç kelime hakkında yukarıda zikrettiğimiz lügavi açıklamalara yer verdikten sonra kastedilenin yıldızlar olduğu görüşüne ve buna dair yapılan açıklamalara değinmiş, görüş sahiplerini zikretmiştir. Sonrasında ise burada kastedilenin geyikler ve antiloplar olduğuna dair görüşün zahire muvafık olmadığını, aksine âyetlerde yıldızların kastedildiğini on maddede ispatlamaya çalışmış; muksamün bih olduğunu iddia ettiği yıldızlar ile muksamün aleyh olan Kur'ân arasındaki irtibata dair açıklamalarda bulunmuş, nihayetinde ise "En doğrusunu Allah bilir" demiştir. ${ }^{55}$

Son asır müfessirlerimizden Şevkânî, Âlûsî, Kasimî ve Merâğî de mezkûr görüşleri zikretmekle beraber yıldızlara kasem edildiği görüşünü tercih etmişlerdir. ${ }^{56}$ İlgili tartışmalara değinen İbn Âşûr da yıldızlara kasem edildiği görüşünü tercih etmekte, bazı sahabilerden ve tabiinden nakledilen, geyik ve antiloplara kasem edildiğine dair görüşü ise tutarlı görmemekte ve Kur'ân'ın âdetinin daha çok Allah'ın

54 Şemsüddin Ebû Abdillah Muhammed b. Ahmed b. Ebî Bekr el-Kurtubî, el-Câmi liAhkâmi'l-Kur'ân (Kahire: Dâru'l-Kitabi'l-Misriyye, 1964), 19/236-237.

55 Muhammed b. Ebî Bekr b. Eyyüb b. Sa'd İbn Kayyim el-Cevziyye, et-Tibyân fî Aksâmi'l-Kur'ân (Beyrut: Dâru'l-Marife, ts.), 115-118.

56 Muhammed b. Ali b. Muhammed eş-Şevkânî, Fethu'l-Kadîr (Dımaşk: Dâru İbn Kesir, 1414 h.), 5/472; Şihâbuddin es-Seyyid Mahmud el-Bağdâdî el-Âlûsî, Rûhu'l-Méânî fî Tefsîri'l-Kur'âni'l-'Azîm ve's-Seb'i'l-Mesânî (Beyrut: Dâru'l-Kütübi'l-'İlmiyye, 1415 h), 15/261-262; Muhammed Cemalüddin el-Kasimî, Mehâsinu't-Te'vîl (Beyrut: Dâru'lKütübi'l-İlmiyye, 1418 h.), 9/418; Ahmed Mustafa el-Merâğî, Tefsîru'l-Merâğ $̂ \hat{~}$ (Misır: Şeriketü Mektebetü ve Matba'atü Mustafa el-Bâbî el-Halebî, 1946), 30/58-59. 
260 | A. AKBAŞ / Tekvîr Sûresi'ndeki “Hunnes", "Cevâri” ve "Künnes” Kelimeleri Bağlamında Bir Bilimsel Tefsir Denemesi

kudretine delalet eden veya mübarek olan şeylere kasem etmek şeklinde olduğunu belirtmektedir. ${ }^{57}$

Elmalılı Hamdi Yazır da farklı görüşleri zikretmiş, mecaz ve istiare konularına uzun uzadıya değindikten sonra diğer müfessirlerden farklı olarak "künnes" kelimesinin asli anlamina odaklanmak gerektiğini, müfessirlerin buna pek dikkat etmediklerini ifade etmiştir. Ona göre burada asli mananın maksut olma ihtimali vardır. Bu durumda şu iki şekilde mana verilebilir: "1. "Kasem ederim o gaybda gizlenenlere, o akıp akıp süpürenlere." Bu durumda, fesat âlemi olan dünyada temizlik yapma işini yerine getirmekle görevlendirilmiş olan meleklere yemin edilmiş olur. 2. "Kasem ederim o sinip sinip dönenlere, o akıp akıp süpürenlere." Bu durumda da "hunnes", dünyaya gelip gidenlere, "elcevâri'l-künnes" de ondan bedel olarak onları alıp ahirete götüren meleklere işaret olmuş olur." Yazır, "Başvurduğum tefsirlerde meleklere işaret olmasına dair bir nakil görmedim, sadece kamuslarda gördüm" demekte, dolayısıyla Mâverdî'nin buna dair ifadesine ulaşamamış görünmektedir. 58

$\mathrm{Bu}$ âyetler hakkında, son dönem müfessirlerinden Abdurrahman Hasan Habenneke el-Meydânî'nin özgün bazı yorumları dikkat çekmektedir. Müfessir öncelikle Tekvîr Sûresi'nin 15. âyetiyle başlayan ikinci kısmında, bazı kevnî hakikatlere kasem edilerek Hz. Peygamber'in nübüvvetinin hak oluşunu tekit etmenin amaçlandığını belirtmekte, ${ }^{59}$ buradaki üç kelime ile yıldızlara yemin edildiğini, bu yeminin de geyiklerin hareketleri için kullanılan kelimelerin istiare yoluyla yıldızlar için kullanılarak yapıldığını, yıldızların da tıpkı geyikler gibi hareket ettiklerini, bazen açığa çıkıp bazen saklandıklarını ifade etmektedir.60 Habenneke diğer müfessirlerden farklı olarak, künnes kelimesinin, asli anlamı olan "bir şeyi bir yerden süpürüp izale etmek" kastıyla kullanılmış olabileceğini, bu şekilde bazı yıldızların, uzay boşluğundaki toz ve kaya parçacıklarını süpürüp kendine doğru çekmesinin de kastedilmiş olabileceğini belirtmektedir. $\mathrm{O}$, bu yorumu ile daha önce zikrettiğimiz tüm müfessirlerden ayrılmakta, "künnes"

57 Muhammed et-Tâhir İbn Âşûr, Tefsîru't-Tahrîr ve't-Tenvîr (Tunus: ed-Dâru'tTûnusiyye, 1984), 30/152-153.

58 Elmalılı M. Hamdi Yazır, Hak Dini Kur'ân Dili (İstanbul: Eser Neşriyat, 1971), 8/5618.

59 Habenneke, Me'âricu't-Tefekkür, 1/398.

60 Habenneke, Me'âricu't-Tefekkür, 1/421. 
kelimesine ilk ve asli anlamını vermekte, yıldızların pek bilinmeyen bir yönüne işaret etmektedir. Akabinde ise yıldızlar âleminin insanı dehşete düşüren ve hayrette birakan muazzam hakikatlerle dolu olduğunu, Kur'ân'ın bu âleme dair kullandığı ifadeler hakkında araştırmalar yapmanın, insaflı araştırmacıları, her şeyi yaratan Allah'a imana, O'nun her şeyi kuşatan bir ilme sahip olduğunu kabule ve sonsuz hikmetini, kudretini ve yaratmadaki mükemmelliğini idrak etmeye götüreceğini belirtmektedir. ${ }^{61}$

\section{Bilimsel Tefsir Metodu Açısından Âyetlerin Tahlili}

Yukarıda da vurguladığımız gibi Tekvîr Sûresi 15-16. âyetlerdeki kelimelerin sözlük anlamlarının müfessirlerce biliniyor olması, bu âyetlere aynı anlamların verilmesini sağlamamıştır. Zira kelimeler, kullanıldıkları bağlamlara göre anlam değişimi ve genişlemesine uğrayabilmekte, mecazi ve hakiki manalar söz konusu olabilmektedir. Bunun da ötesinde işin içerisine müfessirin zihin dünyası, bilgi birikimi, olgu ve olaylara dair tasavvuru girebilmekte, nihayetinde çok farklı yorumlar ortaya çıkmaktadır. Müfessirlerin farklı yaklaşım ve yorumlarını özetlediğimiz bu âyetlerde de aynı durum söz konusu olmuş, burada ceylanlara, geyiklere, antiloplara yemin edildiğini savunanlar olduğu gibi beş yıldıza (Zühal, Müşteri, Merih, Zühre, Utarit), güneş ve ayla beraber yedi yıldıza yahut tüm yıldızlara yahut meleklere yemin edildiğini belirtenler olmuştur. Bu görüşler de öyle alelade kişilerin değil sahabe ve tabiin nesli de dâhil olmak üzere İslam'ın ilk asırlarından itibaren şöhret bulmuş büyük ilim adamlarının görüşleri olup 21. asrın penceresinden bakarak küçümsenebilecek bir seviyede değildirler. Her ne kadar son asırlarda yıldızlara yemin edildiği görüşü baskın hale gelmiş olsa da Taberî'nin kararsızlı̆ını, Mâtürîdı̂'nin hassasiyetini ve Kurtubî'nin, Allah'ın meşietine kota koymak olarak addettiği açıklamalar karşısındaki sert ifadesini dikkate aldığımızda, geyik, antilop vb. hayvanlara yemin edildiğine dair görüşlerin -kabul edilmese dahi- değersiz ve mesnetsiz görülmemesi gerektiği anlaşılmaktadır. Ancak biz, Taberî'nin, kararsızlığını açık sözlülükle ifade etmesini, Râzî'nin tüm delilleri sıraladı̆̆ı halde "En doğrusunu Allah bilir" demesini, birçok müfessirin de aynı güzel ahlakı sergilemesini takdire şayan bulup Hamdi Yazır'ın diğerlerinden nispeten farklı olarak "künnes" kelimesinin asli anlamına odaklanması

61 Habenneke, Me'âricu't-Tefekkür, 1/422. 
262 | A. AKBAŞ / Tekvîr Sûresi'ndeki “Hunnes", "Cevâri” ve "Künnes” Kelimeleri Bağlamında Bir Bilimsel Tefsir Denemesi

ve müfessirlerin bu hususu ihmal ettiklerini söylemesi noktasından hareketle meseleye Habenneke el-Meydânî'nin biraktığ ${ }_{1}$ yerden devam etmek gerektiğini düşünmekteyiz.

Ebû Ubeyde'nin kısa ve öz bir şekilde "Bunlar yıldızlardır" dediğini, devamındaki âyetlerde geceye ve sabaha yemin edilmiş olması hasebiyle burada da yıldızlara yemin edildiği görüşünün çoğu müfessirce daha makul görüldüğünü ifade etmiştik. Kur'ân'da hayvanlara yemin bulunmazken ${ }^{62}$ birçok âyette semavi varlıklara ve kozmik olaylara yemin edilmiş olması da dikkat çekmektedir. Kur'ân'da türlü şekillerde insanların istifadesine sunulduğu belirtilen hayvanlar daha çok ibret ve şükür vesilesi olarak takdim edilmekte ${ }^{63}$ ama bunlara yemin edilmemektedir. Bunun mukabilinde sema, arz, güneş, yıldız, ay, gece, gündüz, sabah, fecir, şafak, kuşluk vakti, asır, kıyamet, incir, zeytin, Sina Dağı, emin belde, nefis, beytü'l-ma'mûr, sakfu'l-merfu', deniz, kalem, kitap, Kur'ân gibi birçok olguya ise yemin edilmektedir. ${ }^{64}$ Müfessirlerimizin belirttiği diğer tüm delillerle birlikte bu hususu da dikkate aldığımızda -Allah'ın dilediği varlığa yemin edebileceğini peşinen kabul etmekle beraber- konumuz olan âyetlerde yıldızlara yemin edilmiş olmasının en sahih görüş olduğunu rahatlıkla söyleyebiliriz.

Ancak bu kabulümüz bu âyetlerin nasıl tefsir edileceğine, buradaki üç kelime ile yıldızların hangi özelliklerine işaret edildiğine dair problemi ortadan kaldırmamaktadır. Zira bu üç kelimeden sadece "akma, hareket etme, hızlıca geçip gitme" anlamını taşıyan "câriye" kelimesiyle ayn kökten müştak "tecrî" kelimesi, birer gök cismi olan güneş ve ay hakkında birçok âyette kullanılmışken65 "hunnes" ve "künnes" kelimeleri hiçbir âyette gök cisimleri hakkında

62 Kur'ân'da hayvanlara yemin olarak sayllabilecek tek örnek Âdiyât Sûresi'nin ilk âyetleridir. Ancak bu âyetlerde hayvanlara yemin edildiği görüşü bir tercih meselesidir. Zira bu âyetlerdeki ifadeler, farklı yorum ve yaklaşımlara da açıktır. Âdiyât Sûresi'ndeki kasemlerin sûre içi irtibatları için bk. Bintü'ş-Şâti, et-Tefsîru'lBeyânî li'l-Kur'âni'l-Kerîm, 1/103-120.

63 el-En'am 6/142; en-Nahl 16/5, 66, 79-80; el-Hacc 22/28, 30, 34, 37; el-Mü'minûn 23/21; Yâsîn 36/71.

64 Muzaffer Gedikoğlu, Arap Dilinde Kasem (Konya: Selçuk Üniversitesi, Sosyal Bilimler Enstitüsü, Yüksek Lisans Tezi, 2006), 60-78; Çalışkan, Kur'ân Dilinde Kasem (Yemin) Üslûbu, 67-142.

65 er-Ra'd 13/2; Lokman 31/29; el-Fâtır 35/13; Yâsîn 36/38; ez-Zümer 39/5. 
kullanılmamıştır. Bu da bizi, burada üzerine kasem edilen yıldızların sıradan yıldızlar değil özel bir yönü olan yıldızlar olduğu, yani bu üç kelime aracılığıyla özel bir yıldız türüne işaret edildiği düşüncesine sevk etmektedir. Zira Kur'ân'da sıradan yıldızlar için başka birçok kelimenin kullanıldığ1, bunların başında da "necm", ${ }^{66}$ "kevkeb", ${ }^{67}$ ve "misbah"68 kelimelerinin geldiği bilinmektedir. Kur'ân'da sıradan yıldızlar değil de özel bir yıldız türü kastedildiğinde farklı kelimelerin kullanılmasına en güzel örnekler, Tarık Sûresi'ndeki "en-necmü's-sâkıb"69 ifadesi ile birçok sûredeki "şihâb" ve "şühüb" kelimeleridir.70 O halde Tekvîr Sûresi'nde özel bir yıldız türüne işaret edildiği açıktır. Bu da bizi, şu ana kadar gök cisimleri hakkında yapılmış olan bilimsel keşiflerden istifade ederek ve her üç kelimenin de asli anlamlarını dikkate alarak bu asli anlamlara muvafık gelen bir yıldız türü olup olmadığı sorusunu sormaya sevk etmekte; tefsirlerde sadece Habenneke el-Meydânî'nin işaret ettiği, bilimsel tefsir alanında öncü isimlerden olan Muhammed Zağlûl enNeccâr'ın ise açıkça savunduğu bir iddia ile karşı karşıya getirmektedir. Bu iddiaya göre bu âyetlerde üç kelime ile işaret edilen yıldız türü "kara delik" olarak tabir edilen yıldızlardır. ${ }^{71}$

Mezkûr âyetlerde belirleyici olan en önemli husus "künnes" kelimesine verilen anlamdır. Zira müfessirler genelde, yıldızların gece görünmelerine, gündüz ise semada mevcut oldukları halde gözle görülmemelerine odaklanarak bu kelimeye ya gündüz gizlenme veya gece yuvasına yani asıl yerine dönüp görünür olma veya kendi burcuna dönme anlamı vermişlerdir. Zaten tefsirlerdeki en temel ihtilaf noktalarından biri de yıldızların hangi hallerinin "hunûs", hangi hallerinin "künûs" olduğu tartışmasıdır ki bu konuda bir görüş birliği

66 en-Nahl 16/12, 16; el-Hacc 22/18; en-Necm 53/1; er-Rahmân 55/6; el-En’am 6/97; elA'râf $7 / 54 \mathrm{vb}$.

67 el-En'am 6/76; Yusuf 12/4; es-Sâffât 37/6 vb.

68 Fussilet 41/12; el-Mülk 67/5.

69 et-Târık 86/1-3.

70 el-Hicr 15/18; en-Neml 27/7; es-Sâffât 37/10; el-Cinn 72/8-9.

71 Tekvîr Sûresi'ndeki bu ifadelerin karadeliklere işaret olduğunu ilk olarak dile getirenlerdendir ve bize ilham kaynağı olmuştur. Bu konudaki görüşleri için bk. Muhammed Zağlûl en-Neccâr, es-Semâu fi'l-Kur'âni'l-Kerîm (Beyrut: Dâru'l-Marife, 2005), 211-233; Ahmet Akbaş, Prof. Dr. Zağlûl en-Neccâr ile Bilimsel Tefsir Üzerine (İstanbul: Nida Yayınları, 2017), 75-90. 
264 | A. AKBAŞ / Tekvîr Sûresi'ndeki “Hunnes", "Cevâri” ve "Künnes” Kelimeleri Bağlamında Bir Bilimsel Tefsir Denemesi

söz konusu değildir.72 Hâlbuki "hunnes" kelimesinde olduğu gibi "künnes" kelimesine de ilk ve asli anlamı olan "bir şeyi bir yerden süpürüp izale etme" anlamı verildiği takdirde yapılan bütün çelişkili yorumlar zail olmakta, adeta taşlar yerine oturmaktadır. Ama yıldızlar hakkında böyle bir bilgiye ve tasavvura sahip olmadıkları içindir ki geçmiş müfessirler "künnes" kelimesini zihinlerinde bir yere oturtmaya çalışmışlar ve birbirine ters düşen yorumlar yapmışlardır. "Künnes" kelimesine asli anlamı verildiği takdirde bazı müfessirlerde olduğu gibi ona da "hunnes" kelimesi gibi gizlenme anlamı yüklemekten kaynaklanan tutarsızlık ortadan kalkmış olur. Ayrıca bu iki âyette bahsedilen yıldızları diğer tüm yıldızlar gibi görüp öyle tefsir ederek hunnes ve künnes kelimelerini necm ve kevkeb kelimeleriyle aynı kabul etmekten kaynaklanan sorun da ortadan kalkmış olur. Zira buradaki kelimeler çok daha özel kelimeler olup bunların özel bir yıldız türüne işaret ediyor olmaları daha tutarlıdır. Burada İbn Düreyd'in işaret ettiği, hayvanın yuvasına girmesi için "kenese" kelimesinin kullanımında dahi aslen "süpürüp izale etme, yeri eşeleyip temizleme" anlamının kastedildiği, yoksa burada doğrudan "girmek-saklanmak" anlamının olmadığı hatırlanmalıdır. Bu nedenlerle âyetteki "künnes" kelimesine Hamdi Yazır'ın dediği gibi asli anlama odaklanarak- Habenneke'nin verdiği anlamı vermek daha doğru ve tutarlı görünmektedir.

Günümüzde -sınırlı da olsa- astronomi biliminin ulaştığı bazı bilgi ve bulgular, uzay boşluğunda bu üç kelimeyle anlatılan vasıflara sahip, hem de âyetlerdeki çoğul ifadeye muvafık olarak çok sayıda yıldızın mevcut olduğunu ortaya çıkarmıştır. "Hunnes" kelimesindeki gizlilik, görünmezlik, sinme ve geriye çekilme; "cevâri" kelimesindeki akıcılık ve hareketli olma; "künnes" kelimesindeki süpürme, temizleme, toplama ve izale etme anlamları birlikte değerlendirildiğinde, burada son yıllarda kısmen keşfedilen ve keşfedilmeye devam eden, bilim insanlarını hayretler içinde bırakan, Allah'ın kudretinin delillerinden olan muazzam bir olguya kasem edildiğini söylemek daha doğru ve tutarlı görünmektedir. Bu olgu her ne kadar yanlış bir isimlendirme ile "karadelikler" olarak bilinse de sadece bu âyetlere bakarak uzay boşluğunda -bu üç kelimeye muvafık olarak- çok gizli ve görünmez olan

72 Makalenin sınırları çerçevesinde bu tartışmalara dair ayrıntıların hepsini verme imkânı bulunmadığı için ilgili başlıklar altındaki dipnotlarda zikrettiğimiz tefsirlere bakılabilir. 
ve/veya geriye çekilen, içe doğru büzüşen; hareket halinde olan ve etrafındaki varlıkları süpürüp izale eden bir yıldız türünün olduğu rahatlıkla söylenebilir.

Mevcut bilimsel keşiflere göre karadeliklerle ilgili eldeki bilgiler şöyledir: ${ }^{73}$ Güneşten çok daha büyük bazı yıldızlar kendi çekim alanlarının etkisi altında, nükleer yakıtlarını tüketip soğuyunca hacimsel olarak milyonlarca kat içe doğru büzüşüp küçülür ve yoğunlaşırlar. Kendi eksenleri etrafındaki turlarını saniyenin binde biri ile 30 saniye arasında bir hızla tamamlayan bu yıldızlara nötron yıldızı denir. Ancak güneşten binlerce hatta milyarlarca kat daha büyük bazı yıldızlarda böyle bir durum yaşandığında, yani taşıdıkları o müthiş çekim gücünün etkisiyle içe doğru çöktüklerinde, çok daha yoğun hatta şu ana dek bilinen en yoğun hale dönüşürler. Böyle bir yıldız, üzerine düşen ışığı dahi çektiği -soğurduğu- ve yansitamadığı için görünemez. Karadelik denen yıldızlar da bunlardır. Karadeliklerin yoğunluğuyla ilgili bir üst sınır yoktur, en yoğun ve çekim kuvveti en yüksek madde olarak bilinirler. Karadelikler, bir delik olmadıkları gibi aslında siyah da değildirler. Işık yaymadıkları için doğrudan gözlemlenemezler. Ancak "olay ufku"nun dışındaki elektrik yüklü parçacıklar, karadeliğin çekim alanına düşüp de ivmelendiklerinde işık yayarlar. Dolayısıyla yoğun madde bulutuyla çevrelenmiş bir karadeliğin ş̧ık halesinin ortasında bir gölge gibi görünmesi bundandır. Karadelikler için önemli bir kavram olan "olay ufku", karadeliğin çevresindeki hayali bir hapishane gibi düşünülebilir. Bu sınıra ulaşan ışık dâhil hiçbir şey artık karadeliğin çekim etkisinden kurtulamaz. Buradan itibaren çıkış ve kaçış mümkün değildir. Karadeliklerin sahip oldukları yoğunluk esas alındığında, bir kestane büyüklüğündeki bir kütle, dünyamızın ağırlığına eşittir.74

$73 \mathrm{Bu}$ konuda şu videolardan da istifade edilebilir: https://www.youtube.com/watch?v=j5nsoL09rFM\&t=1353s;

https://www.youtube.com/watch?v=apXMmC_5TcY; https://www.youtube.com/watch?v=fMoHgZu-XWc\&t=2370s; https://www.youtube.com/watch?v=iaqhSOoH3D8.

74 Stephen Hawking, Kara Delikler, çev. Kerem Cankoçak (İstanbul: Alfa Bilim Yayıncılık, 2018), 20-52; Stephen Hawking, Zamanın Kısa Tarihi, çev. Barış Gönülşen (İstanbul: Alfa Bilim Yayıncılık, 2015), 109-130; Roger Penrose, Zaman Döngüleri, çev. Kerem Cankoçak - Murat Metehan Türkoğlu (İstanbul: Alfa Bilim Yayıncılık, 2015), 105-116; Bayram Tekin, “Kim Korkar Karadelikten” Bilim ve Teknik Dergisi (Ekim 
266 | A. AKBAŞ / Tekvîr Sûresi'ndeki “Hunnes", "Cevâri" ve "Künnes" Kelimeleri Bağlamında Bir Bilimsel Tefsir Denemesi

Uzaydaki bu muazzam olgu hakkında bazı astronomların artık "karadelikler (black holes)" değil, "süper emici süpürgeler (supergiant vacuum cleaners)"75 demesi de enteresan olup "künnes" kelimesine daha uygun bir isimlendirmedir. Karadeliklerin hem görünmez olup hem de içe doğru çöken-büzüşen yıldızlar oluşu da bize "hunnes" kelimesine verilen anlamları hatırlatmaktadır. Hareket halinde olmaları ise "câriye" kelimesini çağrıştırır. Âyetteki üç kelime arasında atıf harfinin olmaması da burada aynı varlığın sıfatlarının sıralandığını göstermekte, kasem edilen varlığın, üç fonksiyonu aynı anda gerçekleştirdiği anlaşılmaktadır. Buna karşın devamında gelen kasemlerdeki gece ve sabah kelimeleri atıf harfleriyle birbirinden ayrılmıştır.

Tekvîr Sûresi'ndeki bu üç kelime ile karadeliklerin kastedildiğine dair iddiamız sunmuş olduğumuz delillere dayanmaktadır. Mevcut bilimsel keşiflerle bu âyetlerdeki ifadeler arasında mutabakatın olduğu görülmektedir. Ancak şu da unutulmamalıdır ki bilimsel verilerde hata olma ihtimali her zaman için mevcuttur. Bir zamanlar bilim adamlarınca, güneşin sabit olduğu iddia edilirken sonraları onun da bir şekilde kendisine tabi olan tüm sistemle birlikte hareket halinde olduğu keşfedilmiş, bu keşif sayesinde Kur'ân'ın açık bir şekilde defalarca ifade ettiği "güneşin akıp gitmekte olduğu"na dair ifadelerin ${ }^{76}$ hakikat olduğu anlaşılmıştır. Bu nedenle Kur'ân'da mevcut olan bilgiler her zaman için esas kabul edilmelidir.

Buradaki yorumlarımızın ardından bize düşen, geçmiş müfessirlerimizden tevarüs ettiğimiz ilim ahlakına uygun olarak "En doğrusunu Allah bilir" demektir.

\section{Sonuç}

Çalışmanın en başında da vurgulandığı üzere Kur'ân, bir bilim kitabı değil, en büyük misyonu tevhit merkezli bir hayat inşa etmek olan hidayet rehberidir. $\mathrm{Bu}$ misyonu gerçekleştirebilmesi ise ancak muhataplarını derinden etkilemesi, zihin ve gönüllerinde üstün bir yer edinmesi ile mümkündür. Bunun tahakkuk etmesi hususunda Kur'ân,

2008), 46-48; Mahir E. Ocak, “İlk Karadelik Görüntüleri, Bilim ve Teknik Dergisi (Mayıs 2019), 14-15.

75 Neccâr, es-Semâu fi'l-Kur'ân, 228; Akbaş, Prof. Dr. Zağlûl en-Neccâr ile Bilimsel Tefsir Üzerine, 52.

76 er-Ra'd 13/12; el-Enbiyâ 21/33; Lokman 31/29; Fâtır 35/13; Yâsîn 36/38. 
tek değil birçok mümeyyiz vasfa sahiptir. Bu vasıfların başında ise muhatapların duygu ve düşüncelerine, kalp ve akıllarına tesir eden dili ve üslûbu gelmektedir. Ancak onun bu dil ve üslûp içerisinde kullandığg özel bazı ifadeler de vardır ki bunlar ilk muhatap nesiller tarafından bir yönüyle veya zahirleri itibariyle anlaşılmış olsalar da delaletleri konusunda çok şey söylenmiş, çok farklı ve birbirini tutmayan yorumlar yapılmıştır. İçerdikleri konular itibariyle daha çok deney ve gözleme dayalı bilimsel alanı ilgilendiren bu ifadeler, son asırda elde edilen bilimsel bilgi ve bulgularla çok daha iyi anlaşılabilen ve delaletlerinin ne olduğu konusunda, lafızlarına muvafık açıklamalar yapılabilen, bu yönüyle de bilimsel tefsir metodunun araştırma sahasına giren ifadelerdir. Kur'ân'ın bu türden ifadeleri üzerine derinlemesine araştırmalar yapmak, onun her asırda yenilenen i'câz yönünü açığa çıarma çabasından ibarettir. Zira o, asırlar öncesinden asırlar sonrasına da hitap edebilen dil ve üslûp özelliklerine sahip bir kitaptır. Onun bu yönünü keşfetmek, bir beşerin değil her şeyi künhüyle bilen Allah'ın kelâmı olduğunu tasdike götürmektedir.

Bu çalışmada ele aldığımız âyetlerde geçen "hunnes", "cevârî" ve "künnes" kelimelerinin delaletleri hakkında geçmiş asırlarda çok şey söylenmiş olması, her yönüyle anlaşıldıkları anlamına gelmemektedir. Bilakis haklarındaki açılamaların sadra şifa olmaması, birbirini nakzeden ve bazen de lafızlarla birebir uyuşmayan görüşler içermesi, bu ifadelerin orijinaline uygun bir şekilde ve asrımızdaki bilimsel birikimden de istifade edilerek yeniden yorumlanmasını zaruri kılmaktadır. Zira bu kelimeler, bilimin de araştırma sahasına giren uzay âlemini ve bu âlemin en önemli varlıkları olan yıldızları ilgilendirmektedir. Günümüzde uzay âlemi ve yıldızlar hakkında ulaşılmış olan bilgi birikiminin, âyetlerin indiği dönemdeki bilgilerle kıyas dâhi edilemeyecek kadar ileri seviyede olduğu aşikârdır. Eldeki bu bilgiler dikkate alındığında bu üç kelime ile ifade edilen bir yıldız türünün yeni yeni keşfedilmeye başlandığ görülmektedir. "Hunnes" kelimesindeki gizlilik, görünmezlik ve geri çekilip büzüşme, "cevârî" kelimesindeki akıcılık ve hareketlilik, "künnes" kelimesindeki süpürme, izale edip toplama anlamları birlikte ele alındığında, bu âyetlerde güçlü bir şekilde üzerine kasem edilen ve dikkat çekilen olgunun "karadelik" olarak isimlendirilen yıldızlar olduğu düşüncesi ağır basmakta, bu 
268 | A. AKBAŞ / Tekvîr Sûresi'ndeki “Hunnes”, “Cevâri” ve "Künnes” Kelimeleri Bağlamında Bir Bilimsel Tefsir Denemesi

yıldız türü ile ilgili bilimsel bilgi ve bulgular, mezkûr kelimelerin asıl anlamlarıla örtüşmektedir.

Âyetlerde üç kelime ile işaret edilen fiziksel bir olgunun Kur'ân'da asırlar öncesinden zikredilmiş olması, sûrenin devamında muksamün aleyh olarak vurgulanan, Kur'ân'ın Allah katından gelen bir kelâm oluşu ile irtibatlıdır. Zira miladi 7. asırda yaşamış ümmi bir insanın ağzından o dönem insanlarının sathi olarak anlasalar da delalet açısından idrak edemedikleri, günümüz insanlarının ise ancak çok ileri seviyedeki keşiflerle tespit edebildikleri fiziksel bir gerçeğin Kur'ân'da zikredilmiş olması, onun bir beşerin değil, her şeyi ilmi ve kudretiyle kuşatmış olan yaratanın kelâmı olduğu hakikatini pekiştirmekte, bu şekilde muksamun bih ile muksamun aleyh arasındaki irtibat da kurulmuş olmaktadır.

Şu da unutulmamalıdır ki meâl veya tefsir olsun Kur'ân'1 açıklamaya dair her girişim, nihayetinde eldeki mevcut verilerden hareketle yapılan yorumlardır ve bir yönüyle içtihattır. Bu nedenle Tekvîr Sûresi 15-16. âyetlerde geçen ifadeler hakkındaki düşüncelerimiz de nihayetinde bizim ulaşmış olduğumuz bazı neticeler ve yorumlardan ibaret olup bunların kesin hakikatler ve değişmez gerçekler olduğunu söylemek doğru değildir. Kur'ân'daki bu tür ifadelerin, zamanımızdaki veya ileriki asırlardaki bazı ilim adamlarınca çok daha iyi anlaşılma veya tashih edilme ihtimali her zaman için mevcuttur.

\section{Kaynakça}

Abdulbâkî, Muhammed Fuâd. el-Mu 'cemu'l-Müfehres li-Elfâzi 'l-Kur'âni'lKerîm. Kahire, Dâru'l-Hadîs, ts.

Akbaş, Ahmet. "Kur'ân Nassının Bilimsel Veriler Işığında Yorumlanmasının İmkân ve Sınırları". İslam ve Yorum. ed. Fikret Karaman.. Malatya: Malatya İlahiyat Vakfı Yayınları, 2017.

Akbaş, Ahmet. Prof. Dr. Ză̆lûl en-Neccâr ile Bilimsel Tefsir Üzerine. İstanbul: Nida Yayınları, 2017.

Akdemir, Salih. Son Çă̆rı Kur'ân. Ankara: Ankara Okulu Yayınları, 2015. Âlûsî, Şihâbuddin es-Seyyid Mahmud el-Bağdâdî. Rûhu'l-Me 'ânî fi Tefsîri'l-Kur'âni'l- 'Azîm ve's-Seb 'i'l-Mesânî. 15 Cilt. Beyrut: Dâru'lKütübi'l-'İlmiyye, $1415 \mathrm{~h}$. 
A. AKBAŞ / An Essay on the Scientific Tafsir in the Context of the Words "Hunnes", "Cevâri" and "Kûnnes" from Surah at-Takwir I 269

Aydın, Şükrü. “Kur'ân'daki Yeminlerde (Aksamu'l-Kur'ân) Çeviri/Anlama Problemi ve Alternatif Muhammed Esed Çevirisi". Uluslararası Sosyal Araştırmalar Dergisi 9/46 (2016), 914-924.

Bağış, Mehmet. Beydâvî Tefsirinde Kur'ân İlimleri ve Tefsir Usûlü. Şırnak: Şırnak Üniversitesi Yayınları, 2018.

Beğavî, Ebû Muhammed el-Hüseyn b. Mes'ûd. Me âlimu't-Tenzîl. 5 Cilt. Beyrut: Dâru İhyâi't-Türâsi'l-'Arabî, $1420 \mathrm{~h}$.

Beyzâvî, Nâsıruddin Ebû Sa'îd Abdullah b. Ömer b. Muhammed eşŞirâzî. Envâru't-Tenzîl ve Esrâru't-Te'vîl. 5 Cilt. Beyrut: Dâru İhyâi'tTürâsi'l-'Arabî, 1418 h.

Bintü'ş-Şâti, Âişe Abdurrahman. et-Tefsîru'l-Beyânî li'l-Kur'âni'l-Kerîm. 2 Cilt. Kahire: Dâru'l-Meârif, ts.

Boynukalın, Ertuğrul. "Yemin". Türkiye Diyanet Vakfi İslâm Ansiklopedisi. 43/417-420. Ankara: TDV Yayınları, 2013.

Cerrahoğlu, İsmail. Tefsir Usûlü. Ankara: Türkiye Diyanet Vakfı Yayınları, 2007.

Cevherî, İsmail b. Hammad. es-Sıhâh. 6 Cilt. Beyrut: Dâru'l-İlmi li'1Melâyîn, 1990.

Coşkun, Muhammed. "Aksâmu'l-Kur'ân: 89/Fecr, 1-14. Âyetleri Örneğinde Yemin İfadelerinin Anlaşılması ve Tercüme Edilmesi". Marmara Üniversitesi Illahiyat Fakültesi Dergisi 46 (2014), 37-68.

Çalışkan, Mustafa. Kur'ân Dilinde Kasem (Yemin) Üslûbu. Adana: Çukurova Üniversitesi, Sosyal Bilimler Enstitüsü, Doktora Tezi, 2016.

Çelik, Ömer. Tefsir Usûlü ve Tarihi. İstanbul: Kampanya Kitapları, 2015.

Dartma, Bahattin. “illmî Bir Tefsir Denemesi: Kur'ân Bağlamında Dünya Dışındaki Gök Cisimlerinde Canlı Varlıkların Olabileceğine Dair". Dinbilimleri Akademik Araştırma Dergisi 4/4 (2004), 7-15.

Ebû Hayyân, Muhammed b. Yusuf b. Ali el-Endelüsî. el-Bahru'l-Muhît. 10 Cilt. Beyrut: Dâru'l-Fikr, 1420 h.

Ebû Ubeyde, Ma'mer b. el-Müsennâ. Mecâzü'l-Kur'ân. 2 Cilt. Kahire: Mektebetü'l-Hancî, 1381 h.

Ebü's-Suûd, Muhammed b. Muhammed el-'İmâdî. İrşâdu'l-'Akli's-Selîm ilâ Mezâya'l-Kur'âni'l-Kerîm. 9 Cilt. Beyrut: Dâru İhyâi't-Türâsi'l'Arabî, ts. 
270 | A. AKBAŞ / Tekvîr Sûresi'ndeki “Hunnes", "Cevâri” ve "Künnes” Kelimeleri Bağlamında Bir Bilimsel Tefsir Denemesi

Ekinci, Kutbettin. “Kur'ân'da Allah'ın Zatı Dışında Kullanılan Yeminleri Sözün Maksadı Açısından Anlamak". Ankara Üniversitesi İlahiyat Fakültesi Dergisi 57/1 (2016), 85-102.

Ensari, Abdurrahman. el-Mürşidüll-Vecîz ilâ 'Ulûmi'l-Kur'âni'l-Azîz. İstanbul: Nida Yayınları, 2016.

Eren, Cüneyt, "Bilimsel Tefsir Metodolojisi". İslami İlimlerde Metodoloji/Us ûl Meselesi. ed. İsmail Kurt - S. Ali Tüz. İstanbul: Ensar Neşriyat, 2005.

Ezherî, Ebû Mansur Muhammed b. Ahmed. Tehzîbü'l-Lü̆ğa. 15 Cilt. Misır: el-Müessetü'l-Misriyyetü'l-'Âmme, 1964.

Ferâhidî, Halil b. Ahmed. Kitabu'l-'Ayn. 4 Cilt. Beyrut: Dâru'l-Kütübi'lİlmiyye, 2003.

Ferrâ, Ebû Zekeriyya Yahya b. Ziyâd. Me'âni’l-Kur'ân. 3 Cilt. Misır: Dâru'l-Misriye, ts.

Gazzâlî, Ebû Hâmid Muhammed. İhyâu Ulumi'd-Din. 4 Cilt. Beyrut: Dâru İbn Hazm, 2005.

Gedikoğlu, Muzaffer. Arap Dilinde Kasem. Konya: Selçuk Üniversitesi, Sosyal Bilimler Enstitüsü, Yüksek Lisans Tezi, 2006.

Güllüce, Veysel. "Rahman Sûresi 24. Âyetteki el-Cevârî Kelimesi Hakkında Farklı Bir Yorum ve Değerlendirmesi". Ekev Akademi Dergisi 1/4 (1999), 123-134.

Güllüce, Veysel. Bilimsel Tefsirde Usûl. Erzurum: Aktif Yayınevi, 2007.

Güncel Türkçe Sözlük. Erişim 06.10.2020. http://sozluk.gov.tr.

Habenneke, Abdurrahman Hasan el-Meydanî. Kavaidü't-Tedebbüri'lEmsel li Kitabillahi Azze ve Cell. Dımaşk: Dâru'l-Kalem, 2009.

Habenneke, Abdurrahman Hasan el-Meydânî. Me'âricu't-Tefekkür ve Dekaiku't-Tedebbür. 15 Cilt. Dımaşk: Dâru'l-Kalem, 2000.

Hawking, Stephen. Kara Delikler. çev. Kerem Cankoçak. İstanbul: Alfa Bilim Yayıncilık, 2018.

Hawking, Stephen. Zamanın Kısa Tarihi. çev. Barış Gönülşen. İstanbul: Alfa Bilim Yayıncilık, 2015.

Heyet. el-Mu'cemü'l-Vesît. ed. Şevki Dayf. Kahire: Mektebetü'ş-Şürûk, 2004.

İbn Âşûr, Muhammed et-Tâhir. Tefsîru't-Tahrîr ve't-Tenvîr. 30 Cilt. Tunus: ed-Dâru't-Tûnusiyye, 1984. 
İbn Atiyye, Ebû Muhammed Abdulhakk b. Ğâlib el-Endelüsî. elMuharraru'l-Vecîz fî̀ Tefsîri'l-Kitâbi'l-'Azîz. 6 Cilt. Beyrut: Dâru'lKütübi'l-'İlmiyye, $1422 \mathrm{~h}$.

İbn Düreyd, Ebû Bekr Muhammed b. el-Hasan. Cemheretü'l-Lüğa. 3 Cilt. Beyrut: Dâru'l-İlmi li'l-Melâyîn, 1987.

İbn Fâris, Ebü'l-Hüseyn Ahmed. Mu'cemu Mekayîsi'l-Luğa. 6 Cilt. Dımaşk: Dâru'l-Fikr, 1979.

İbn Kayyim, Muhammed b. Ebî Bekr b. Eyyüb b. Sa'd el-Cevziyye. etTibyân fí Aksâmi'l-Kur'ân. Beyrut: Dâru'l-Marife, ts.

İbn Kesir, Ebü'l-Fidâ İsmail b. Amr ed-Dimaşkî. Tefsîru'l-Kur'âni'l- 'Azîm. 8 Cilt. by.: Dâru Taybe, 1999.

İbn Kuteybe, Ebû Muhammed Abdullah b. Müslim ed-Dîneverî. Kitâbu'l-Cerâsîm. 2 Cilt. Dimaşk: Vizâretü's-Sekafe, ts.

İbn Manzûr, Ebü'l-Fadl Cemâlüddin Muhammed b. Mükerrem b. Ali b. Ahmed. Lisânu'l-'Arab. 55 Cilt (6 Mücelled). Kahire: Dâru'lMe`ârif, 1981.

İbn Sikkît, Ebû Yusuf Yakub b. İshak. el-Kenzü’l-Lü̈̆avî. Kahire: Mektebetü'l-Mütenebbî, ts.

İbnü'l-Cevzî, Ebü'l-Ferec Cemâlüddin Abdurrahman b. Ali b. Muhammed. Zâdu'l-Mesîr fì 'İlmi't-Tefsîr. 4 Cilt. Beyrut: Dâru'lKitabi'l-'Arabî, 1422 h.

İsfahânî, Ebü'l-Kâsım Hüseyin b. Muhammed b. Mufaddal er-Râgib. Mu 'cemu Müfredâti Elfâzi'l-Kur'ân. Beyrut: Dâru'l-Kütübi'l-İlmiyye, 1997.

Karadâvî, Yusuf. Kur'ân'ı Anlamada Yöntem. çev. M. Nurullah Aktaş. İstanbul: Nida Yayınları, 2015.

Karaman Hayrettin vd.. Kur'ân Yolu. 5 Cilt. Ankara: Diyanet İşleri Başkanlığı Yayınları, 2014.

Kasimî, Muhammed Cemalüddin. Mehâsinu't-Te'vîl. 9 Cilt. Beyrut: Dâru'l-Kütübi'l-İlmiyye, 1418 h.

Kırca, Celal. "Aksâmu'l-Kur'ân". Türkiye Diyanet Vakfi İslâm Ansiklopedisi. 2/290-291. Ankara: TDV Yayınları, 1989.

Kurtubî, Şemsüddin Ebû Abdillah Muhammed b. Ahmed b. Ebî Bekr. elCâmi' li-Ahkâmi'l-Kur'ân. 20 Cilt. Kahire: Dâru'l-Kitabi'l-Mısriyye, 1964.

Mâtürîdî, Muhammed b. Muhammed b. Mahmûd Ebû Mansur. Te'vilâtü Ehli's-Sünne. 10 Cilt. Beyrut: Dâru'l-Kütübi'l-İlmiyye, 2005. 
272 | A. AKBAŞ / Tekvîr Sûresi'ndeki “Hunnes", "Cevâri” ve "Künnes” Kelimeleri Bağlamında Bir Bilimsel Tefsir Denemesi

Mâverdî, Ebü'l-Hasan Ali b. Muhammed b. Habîb. en-Nüketü ve'l-'Uyûn. 6 Cilt. Beyrut: Dâru'l-Kütübi'l-'İlmiyye, ts.

Merâğ̂̀, Ahmed Mustafa. Tefsîru'l-Merâğ̂̀i. 30 Cilt. Misır: Şeriketü Mektebetü ve Matba'atü Mustafa el-Bâbî el-Halebî, 1946.

Mevdûdî, Ebü'l-A'lâ. Tefhîmu'l-Kur'ân. çev. Muhammed Han Kayani vd.. 7 Cilt. İstanbul: İnsan Yayınları, 1996.

Neccâr, Muhammed Zağlûl. es-Semâu fi'l-Kur'âni'l-Kerîm. Beyrut: Dâru'lMarife, 2005.

Neccâr, Muhammed Zağlûl. Kadiyyetü'l-I'cazi'l-İlmî. Amman: Cem'iyyetü'l-Muhafaza 'ala'l-Kur'âni'l-Kerîm, 2005.

Nehhâs, Ebû Cafer Ahmed b. Muhammed. İ'râbu'l-Kur'ân. 5 Cilt. Beyrut: Dâru'l-Kütübi'l-İlmiyye, $1421 \mathrm{~h}$.

Nursi, Said. Sözler. İstanbul: Sözler Yayınları, ts.

Nursi, Said. Mektûbât. İstanbul: Sözler Yayınları, ts.

Ocak, Mahir E. "Illk Karadelik Görüntüleri". Bilim ve Teknik Dergisi (Mayis 2019), 12-25.

Ömer, Ahmed Muhtar. Mu'cemü'l-Lüğati'l-Arabiyyeti'l-Mu'asıra. 4 Cilt. Kahire: Âlemü'l-Kütüb, 2008.

Penrose, Roger. Zaman Döngüleri. çev. Kerem Cankoçak - Murat Metehan Türkoğlu. İstanbul: Alfa Bilim Yayıncllık, 2015.

Râzî, Fahruddin Muhammed. Mefâtîhul-Ğayb. 32 Cilt. Beyrut: Dâru İhyâi't-Türâsi'l-'Arabî, 1420 h.

Semerkandî, Ebü'l-Leys Nasr b. Muhammed b. Ahmed. Bahru'l- 'Ulûm. 3 Cilt. Beyrut: Dâru'l-Kütübi'l-İlmiyye, 1993.

Semîn el-Halebî, Ahmed b. Yusuf b. Abdiddâim. ed-Dürrü'l-Mesûn fi 'Ulûmi'l-Kitabi'l-Meknûn. 11 Cilt. Dımaşk: Dâru'l-Kalem, ts.

Şevkânî, Muhammed b. Ali b. Muhammed. Fethu'l-Kadîr. 6 Cilt. Dımaşk: Dâru İbn Kesir, 1414 h.

Taberî, Ebû Cafer Muhammed b. Cerîr. Câmi 'u'l-Beyân 'an Te'vili Âyi'lKur'ân. 24 Cilt. b.y.: Müessetü'r-Risâle, 2000.

Tekin, Bayram. "Kim Korkar Karadelikten". Bilim ve Teknik Dergisi (Ekim 2008), 44-48.

Temizkan, Abdullah. "Bilimsel Tefsire Farklı Bir Yaklaşım: Zağlûl Neccâr Örneği". e-Şarkiyat İlmi Araştırmalar Dergisi 10/1 (19) (2018), 39-67.

Topuzoğlu, Tevfik Rüştü. “Halil b. Ahmed”. Türkiye Diyanet Vakfı İslâm Ansiklopedisi. 15/309-312. Ankara: TDV Yayınları, 1997. 
A. AKBAŞ / An Essay on the Scientific Tafsir in the Context of the Words "Hunnes", "Cevâri" and "Kûnnes" from Surah at-Takwir | 273

Turan, Abdulbaki. "Kur'ân-1 Kerîm'de Yeminler (Aksâmu'l-Kur'ân)". Selçuk Üniversitesi İlahiyat Fakültesi Dergisi 2/2 (1986), 97-114.

Yazır, Elmalılı M. Hamdi. Hak Dini Kur'ân Dili. 10 Cilt. İstanbul: Eser Neşriyat, 1971.

Zebîdî, Muhibbuddin Ebü'l-Feyz Muhammed Murtaza el-Hüseynî. Tâcu'l-'Arûs min Cevâhiril-Kamûs. 40 Cilt. Kuveyt: Matbaatu Hukûmeti'l-Kuveyt, 1965.

Zeccâc, Ebû İshak İbrahim b. es-Seriyy. Me'âni'l-Kur'ân. 5 Cilt. Beyrut: Âlemü'l-Kütüb, 1988.

Zemahşerî, Ebü'l-Kasım Cârullah Mahmud b. Ömer. Esâsü'l-Belâ̆ğa. 2 Cilt. Beyrut: Dâru'l-Kütübi'l-İlmiyye, 1998.

Zemahşerî, Ebü'l-Kasım Cârullah Mahmud b. Ömer. Tefsîru'l-Keşşâf 'an Hakaiki't-Tenzîl ve 'Uyûni'l-Ekavîl fî̀ Vücûhi't-Te'vîl. 4 Cilt. Beyrut: Dâru'l-Kitabi'l-'Arabî, 1407 h.

Zerkanî, Muhammed Abdulazim. Menâhilü'l-'irfân fì 'Ulûmi'l-Kur'ân. 2 Cilt. Beyrut: Dâru'l-Marife, 2005. 